\title{
Ecologically Important Reactions and Phenomena in the Mesosphere between the Two Global Ozone Layers
}

\author{
Kari Hänninen \\ Department of Biological and Environmental Sciences, University of Jyväskylä, Finland
}

Copyright $\bigcirc 2018$ by authors, all rights reserved. Authors agree that this article remains permanently open access under the terms of the Creative Commons Attribution License 4.0 International License

\begin{abstract}
Due to their buoyance, methane and water vapor $\left(\mathrm{H}_{2} \mathrm{O}_{(\mathrm{g})}\right)$ ascend into the mesosphere where they are destroyed by chemical reactions or photolysis. In the mesosphere at 81 to $83 \mathrm{~km}, \mathrm{H}_{2} \mathrm{O}_{(\mathrm{g})}$ condenses to ice which then, due to the lack of buoyance, descends to 70 to $75 \mathrm{~km}$ where ice sublimates back to $\mathrm{H}_{2} \mathrm{O}_{(\mathrm{g})}$. A mesospheric minicycle of water forms. In boreal summer evenings the ice layer is visually observable from the ground as noctilucent clouds (NLC). The middle mesospheric ozone maximum (MMM) forms in the wintertime at a height of 70 to $75 \mathrm{~km}$. It is located between the mid-latitudes and somewhat north from the Arctic Circle, and symmetrically in the Southern Hemisphere. In the daytime solar radiation keeps the ozone concentration at a low level. During the civil and nautical twilight the intensity of the sun's rays decrease dramatically. Ozone gains from this decrease most. At high latitudes the solar radiation angle $\left(\theta_{\mathrm{s}}\right)$ decreases more slowly than at the mid-latitudes. IR radiation has more time to photoexcite $\mathrm{O}_{2}\left({ }^{1} \Delta_{g}\right)$ and triplet state ozone $\left(\mathrm{O}_{3} *\right) . \quad \mathrm{O}_{2}\left({ }^{1} \Delta_{g}\right)$ maintains the ozone concentration and $\mathrm{O}_{3} *$ spontaneously provides oxygen atoms. As a result, the amplitude of the MMM layer in terms of ozone concentration increases towards the high latitudes.
\end{abstract}

Keywords Buoyance of Methane and Water Vapor in the Atmosphere, Mesospheric Minicycle of Water Vapor and Ice, Noctilucent Clouds, Photoexcitation of Ozone by IR, Middle Mesospheric Maximum of Ozone, Abiotic Formation of Oxygen Molecules by Photolysis of Water

\section{Introduction}

The mesosphere is the layer between the altitudes of 50 to $55 \mathrm{~km}$ and 85 to $90 \mathrm{~km}$ above Earth's surface. Below the mesosphere, the stratopause separates this layer from the stratosphere and above it the mesopause separates it from the thermosphere. The altitude of the mesopause may vary seasonally between 86 and $100 \mathrm{~km}$ [1].

Verniani and Viani [2] studied the atmospheric temperature at an altitude of $90 \mathrm{~km}$ for each month of the year in 1962. They found that a minimum temperature of $170 \mathrm{~K}$ is reached in May and a maximum of $207 \mathrm{~K}$ in November. They also investigated the diurnal variation of the temperature and found a deep minimum of $162 \mathrm{~K}$ at 2300 hours and a shallow maximum of $197 \mathrm{~K}$ at 1000 hours. The deep night minimum appears to occur in all seasons.

In situ measurements in the mesosphere are difficult. The mesosphere lies between the maximum altitude for most aircraft and the minimum altitude for most spacecraft, so it is directly accessible only through the use of sounding rockets. As a result, it is one of the most poorly understood regions of the atmosphere. Solid objects entering Earth's atmosphere from space usually have such a high speed that they start burning at an altitude of $120 \mathrm{~km}$ as a result of friction caused by collisions with gas particles [3]. Most of the burning takes place in the mesosphere. If large meteoroids contain ice [4], they subsequently disintegrate.

Space rocks smaller than about 25 meters (about $10 \mathrm{t}$, if irregularly shaped) will mostly ablate as they enter Earth's atmosphere and cause little or no damage [5]. These "moderately sized" meteoroids have survived to the point where they have completely lost their cosmic velocity and begin to fall to the ground under the force of gravity [6]. Thus the mesosphere protects Earth from meteoroids.

Historically, atmospheric ozone has been measured during the daytime by UV spectrometers in the presence of ozone photolysis. Ozone also reradiates energy, which emits at longer wavelengths in all directions. This thermal emission of ozone can be observed at the microwave frequencies. Based on their previous calculations and experiments on the transmission of infrared emissions at $1.27 \mu \mathrm{m}$ in the atmosphere [7], Evans and Llewellyn [8] were the first to use this technique to detect the secondary ozone maximum in daytime. A year later, Hays and Roble [9] used the stellar occultation method (applicable to 
spectrometers) to show the presence of this maximum at night. This maximum has been named according to its location as the upper mesospheric and lower thermospheric ozone maximum (MLT).

Locating the MLT layer was an important factor in directing attention to the mesosphere. Techniques for measuring the ozone began receiving more interest. Sophisticated instruments were developed, such as the Cryogenic Infrared Spectrometers and Telescopes for the Atmosphere (CRISTA) [10], the Microwave Limb Sounder (MLS) [11-12], the Michelson Interferometer for Passive Atmospheric Sounding (MIPAS) [13] and the Solar Backscatter Ultraviolet/2 (SBUV/2) [14-16].

In the 1990s the work resulted in the discovery of a third ozone maximum, which was named according to its location as the middle mesospheric (tertiary) maximum of ozone (MMM). The MMM layer is at an altitude of 70 to $75 \mathrm{~km}$, between the northern mid-latitudes (about $45^{\circ} \mathrm{N}$ ) and somewhat north from the Arctic Circle, and symmetrically in the Southern Hemisphere. The annual variation in nighttime mesospheric ozone is characterized by a maximum in wintertime and a minimum in summertime. Daytime mesospheric ozone does not show any distinct annual variation [17]. The diurnal variation in the MMM layer is characterized by an increase of ozone just before darkness, and by a decrease just before sunrise.

Below the MLT layer there is a very deep ozone minimum layer around $80 \mathrm{~km}$, which can be seen in both the number density and the mixing ratio. The lowest ozone concentrations values are $4 \times 10^{7}$ molecule $/ \mathrm{cm}^{3}$ for the number density and $0.13 \mathrm{ppm}$ for the mixing ratio, and they are found in January at the equator [18].

Noctilucent clouds (NLC) are cloud-like phenomena so faint that they can only be observed visually during twilight hours (i.e., when the sun is below the horizon illuminating the cloud against a dark background). The first published records of these phenomena were in 1885 by Jesse [19], Leslie [20] and Backhouse [21] two years after the Krakatau eruption: "Ever since the sunset of 1883 and last year there has been at times an abnormal glare both before and after sundown" [20]. By photographic triangulation their height was measured to be around $82 \mathrm{~km} \mathrm{[22].} \mathrm{By} \mathrm{the}$ beginning of the 20th century it was established that they occur mainly during the summertime in both hemispheres at latitudes greater than $50^{\circ}$ and that they are geometrically confined to a 1 to $3 \mathrm{~km}$ layer [23]. When viewed from space these clouds are termed polar mesospheric clouds (PMCs) and have been detected mostly by measuring scattered solar radiation either in the visible or in the UV part of the spectrum [24]. Hervig et al. [25] confirmed that water ice is the primary component of polar mesospheric clouds.

\section{Materials and Methods}

\section{Discussion}

\subsection{Movements of Methane and Water Vapor in the Atmosphere}

\subsubsection{Movements of methane}

According to Archimedes' principle, buoyancy (lift) is an upward force exerted by a fluid or a gas that opposes an object's weight. The amount of lift provided by the hot air depends on the density difference between the air inside and outside of the balloon envelope caused by different temperatures. The STP density $\left(0^{\circ} \mathrm{C}\right.$ and $\left.1 \mathrm{~atm}\right)$ of air is $1.2928 \mathrm{~kg} / \mathrm{m}^{3}$ and that of methane is $0.7167 \mathrm{~kg} / \mathrm{m}^{3}$. Methane is more than $44 \%$ lighter than STP air. The 
density difference is so great that immediately after formation the trajectory of the methane molecule would be upwards, regardless of ambient temperature. Even winds cannot overcome the force created by buoyance. Trade winds continually carry air (and methane) to the equator from the Tropic of Cancer and the Tropic of Capricorn. According to MIPAS measurements at the equator (see Figure 1), between the latitudes of $10^{\circ} \mathrm{S}$ to $0^{\circ} \mathrm{S}$ the methane volume mixing ratio (VMR) peaks around $15 \mathrm{~km}$ (green line) [28]. When the air carried by the trade winds reaches the equator, methane molecules are already high in the atmosphere. Between the latitudes of $55^{\circ} \mathrm{N}$ to $75^{\circ} \mathrm{N}$, there is no equivalent peaking. Those regions have no winds with a directional continuity even close to that of the trade winds.

\subsubsection{Movements of water vapors and ice}

Water vapor $\left(\mathrm{H}_{2} \mathrm{O}_{(\mathrm{g})}\right)$ represents a small but environmentally significant constituent of the atmosphere.
Approximately $99.13 \%$ of it is in the troposphere. Depending on the ambient temperature, tropospheric $\mathrm{H}_{2} \mathrm{O}_{(\mathrm{g})}$ as a whole is constantly depleted by precipitation as rain or snow and replenished by the evaporation of $\mathrm{H}_{2} \mathrm{O}_{(\mathrm{g})}$ within a relative narrow temperature range. Methane does not undergo similar physical phase changes in the atmosphere of Earth.

The density of $\mathrm{H}_{2} \mathrm{O}_{(\mathrm{g})}$ is $0.804 \mathrm{~kg} / \mathrm{m}^{3}$ [29], making it $38 \%$ lighter than the ambient air. The density difference is so great that in the atmosphere, the trajectory of the water molecule would be, due to buoyancy, upwards.

Even winds cannot overcome the force created by buoyance. During the Airborne Tropical TRopopause EXperiment (ATTREX) field campaign, vertical water profiles between 14 and $18 \mathrm{~km}$ in the tropical Pacific were measured [30]. The water profile peaks at $15 \mathrm{~km}$ due to the $\mathrm{H}_{2} \mathrm{O}_{(\mathrm{g})}$ carried by the trade winds towards the equator (see Figure 2).
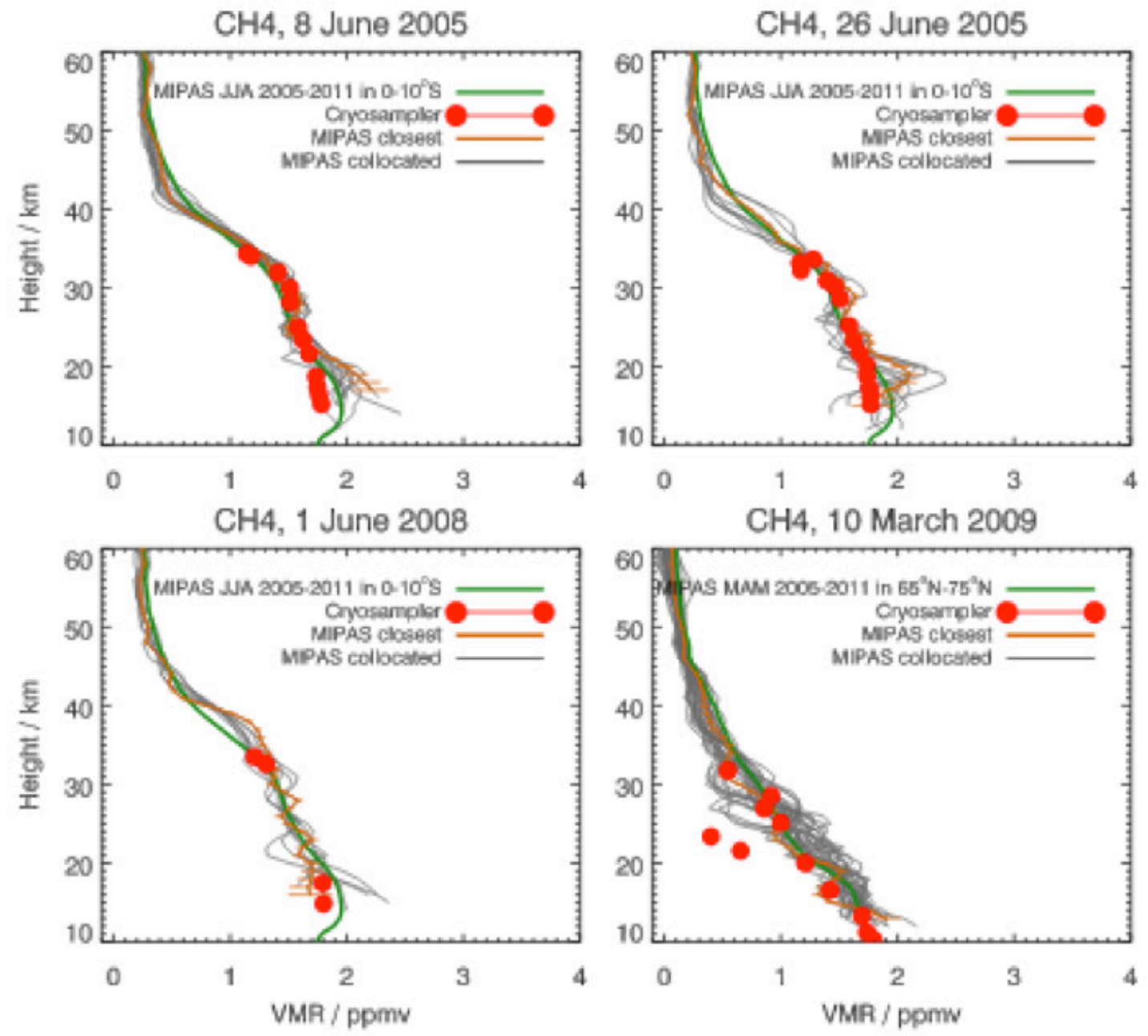

Figure 1. Methane VMR profiles from the upper troposphere to the lower mesosphere [28]. 

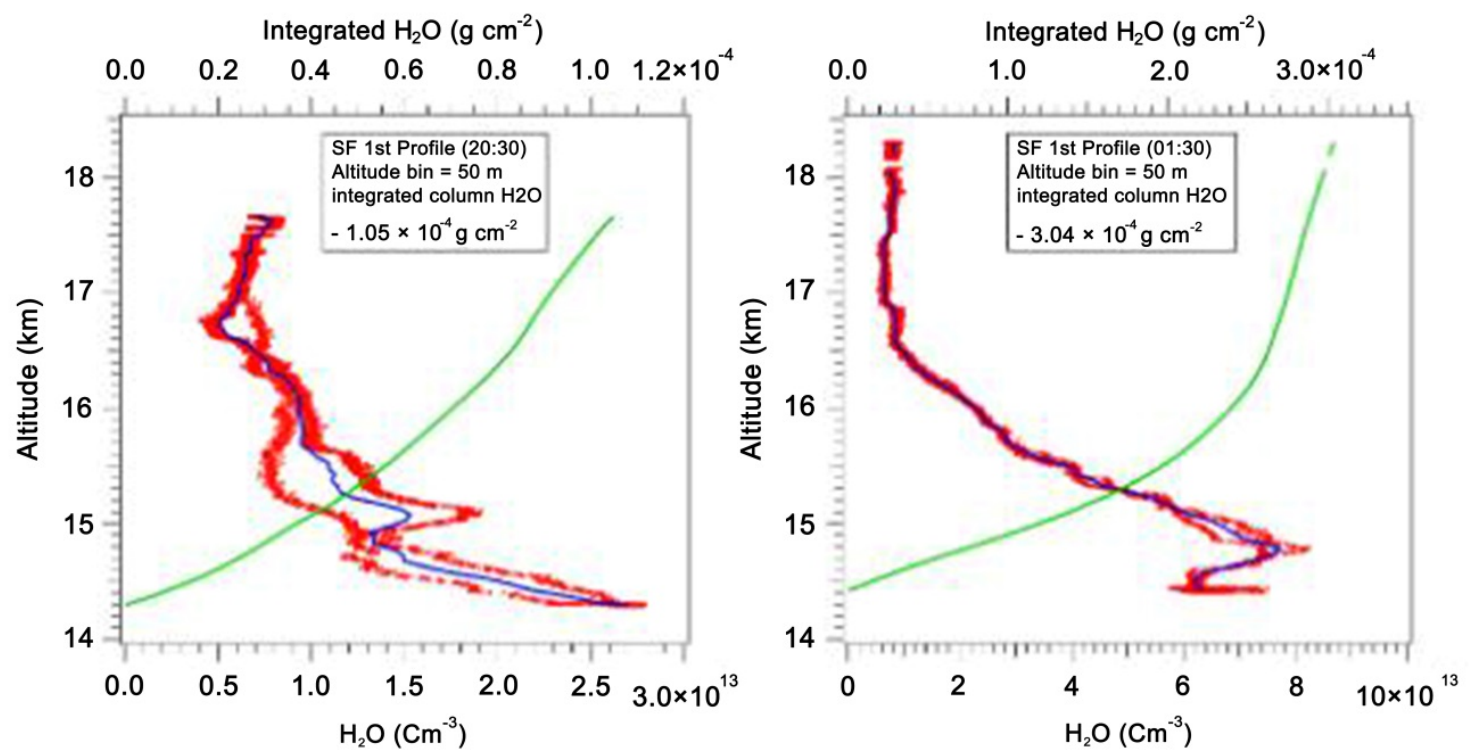

Figure 2. Water vapor number density profiles from the NOAA water instrument. The red points correspond to the in situ water vapor number densities during the descent and ascent for the two profiles. The blue line is the mean of the ascent and descent number densities. The green line is the integrated water vapor amounts (scale at the top of the plot). Note the water peak at around $15 \mathrm{~km} \mathrm{[30].}$

The densities of liquid water and ice at $0^{\circ} \mathrm{C}$ are 998 $\mathrm{kgm}^{-3}$ and $918.7 \mathrm{kgm}^{-3}$, respectively. At $-100^{\circ} \mathrm{C}(173 \mathrm{~K})$ the density of ice is as high as $927 \mathrm{~kg} / \mathrm{m}^{3}$ [31]. In its liquid and solid state, water lacks buoyancy everywhere in the atmosphere. Water vapor moves upward whereas liquid water and ice descend.

Due to trade winds, the tropical tropopause is at an altitude of about $18 \mathrm{~km}$, and the temperature there is $195 \mathrm{~K}$. The extratropical tropopause is at an altitude of 8 to $12 \mathrm{~km}$, and the temperature there is $215 \mathrm{~K} \mathrm{[32].}$

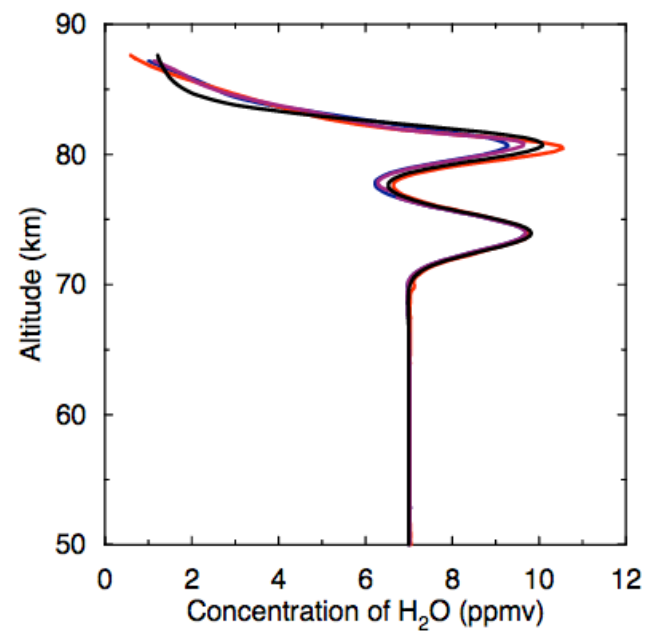

Figure 3. Concentration of $\mathrm{H}_{2} \mathrm{O}$ in the mesosphere [37].

The tropopause works as a first atmospheric cold trap where the freeze-drying of $\mathrm{H}_{2} \mathrm{O}_{(\mathrm{g})}$ and subsequent sedimentation of ice particles strongly reduces the amount of $\mathrm{H}_{2} \mathrm{O}_{(\mathrm{g})}$ entering the stratosphere. The part of water that remains as gas at the top of troposphere enters the stratosphere by vertical transport (caused by the buoyance) through the tropopause transition layer (TTL). Seasonal variation of entry mixing ratios (estimated from near tropical tropopause level measurements) ranges from 2.5 ppmv during January-February to 4.5 ppmv during September-October [33]. Measurement of $\mathrm{H}_{2} \mathrm{O}_{(\mathrm{g})}$ mixing ratios in the extratropical tropopause are rare. In December in Kiruna, Sweden there was 4.2 ppmv of $\mathrm{H}_{2} \mathrm{O}_{(\mathrm{g})}$ in the tropopause [34].

In the stratosphere the temperature increases due to increasing altitude. As warm air is able to contain more water than cold air, the $\mathrm{H}_{2} \mathrm{O}_{(\mathrm{g})}$ concentration increases as well [36]. When the maximum stratospheric temperature is achieved at around 45 to $50 \mathrm{~km}$ [36], the stratospheric $\mathrm{H}_{2} \mathrm{O}_{(\mathrm{g})}$ concentration reaches its maximum value as well.

In the mesosphere, the concentration of $\mathrm{H}_{2} \mathrm{O}_{(\mathrm{g})}$ in general decreases slightly with increasing altitude due to the decreasing temperature and increasing volume of the available space. There are, however, two water peaks as exceptions from this general mesospheric behavior. The upper peak is at an altitude of 81 to $83 \mathrm{~km}$, and the lower peak is around 70 to $75 \mathrm{~km}$. This double maximum is typical especially in the equatorial region (see Figure 3 ) [37-38]. The second atmospheric cold trap is located at an altitude of 81 to $83 \mathrm{~km}$. There the $\mathrm{H}_{2} \mathrm{O}_{(\mathrm{g})}$ condense in the cold of the night around metallic condensation nuclei and form tiny nanocrystalline ice particles (see section 3.6.1). While forming they already descend. When they reach an altitude of 70 to $75 \mathrm{~km}$, they sublimate as water vapor due to the higher temperature.

When conditions are right, with the low angle of entering sunrays in the polar summer time, the highest peak is visually observable in the polar summer as NLCs. 


\subsection{Destruction of Methane}

\subsubsection{Abstraction of $\mathrm{H}$ from $\mathrm{CH}_{4}$ by chemical reaction}

The separate experimental bond enthalpies of $\mathrm{CH}_{4}$ and its constituent radicals are as follows: $\mathrm{D}_{0}\left(\mathrm{CH}_{4}-\mathrm{H}\right)=439.3$ $\mathrm{kJ} / \mathrm{mol} \mathrm{D}\left(\mathrm{CH}_{3}-\mathrm{H}\right)=462.9 \mathrm{~kJ} / \mathrm{mol}, \mathrm{D}_{0}\left(\mathrm{CH}_{2}-\mathrm{H}\right)=423.8$ $\mathrm{kJ} / \mathrm{mol}$ and $\mathrm{D}_{0}(\mathrm{CH}-\mathrm{H})=338.5 \mathrm{~kJ} / \mathrm{mol}$. It is important to note that when these four independently measured bond enthalpies are combined, they give, according to the first law of thermodynamics, $\Delta_{\mathrm{rxn}} \mathrm{H}_{298}\left(\mathrm{CH}_{4} \rightarrow \mathrm{C}+4 \mathrm{H}\right)=1663.1$ $\mathrm{kJ} / \mathrm{mol}$ [39].

In the stratosphere the ascending methane molecules are already considerably consumed by collision reactions (see Figure 1). The most important reactant is the $\mathrm{O}\left({ }^{1} \mathrm{D}\right)$. Its energy content is $438.9 \mathrm{~kJ} / \mathrm{mol}$, which is less than the 439.3 $\mathrm{kJ} / \mathrm{mol}$ needed for direct abstraction of the first hydrogen atom from a methane molecule. A plausible mechanism may be an insertion of $\mathrm{O}\left({ }^{1} \mathrm{D}\right)$ into the methane structure. A transient collision complex of $\left(\mathrm{CH}_{3} \mathrm{OH}\right)^{*}$ is then formed without the need for any activation energy. Due to the sensitization, the energy needed for the abstraction of $\mathrm{OH}$ from $\left(\mathrm{CH}_{3} \mathrm{OH}\right)^{*}$ is much less than that for direct abstraction of $\mathrm{H}$ from $\mathrm{CH}_{4}$. A unimolecular exothermic decomposition follows (reaction 3) [40]:

$\mathrm{O}\left({ }^{1} \mathrm{D}\right)+\mathrm{CH}_{4} \rightarrow\left(\mathrm{CH}_{3} \mathrm{OH}\right)^{*} \rightarrow \mathrm{CH}_{3}+\mathrm{OH} ; \Delta \mathrm{H}^{\circ} \approx-160 \mathrm{~kJ} / \mathrm{mol}$.

\subsubsection{Abstraction of $\mathrm{H}$ from $\mathrm{CH}_{4}$ by photolysis}

The UV absorption spectrum of methane lies in the vacuum ultraviolet (VUV) region in the range of 105 to $165 \mathrm{~nm}$ [41]. Intensive photodissociation of methane occurs at wavelengths $\lambda \leq 140 \mathrm{~nm}$ and reaches its peak between 130 and $105 \mathrm{~nm}$.

Methane photolysis has been the subject of many theoretical and experimental studies, but a complete understanding of the process has not yet been achieved [42]. The longest wavelength at which methane can absorb UV photons is $165 \mathrm{~nm}$. Methane molecules encounter this caliber of UV in the mesopause. The energy of the $165 \mathrm{~nm}$ UV photon $(725 \mathrm{~kJ} / \mathrm{mol})$ is enough to abstract an $\mathrm{H}$ atom from a methane molecule. The limiting factor then is a small absorption coefficient.

UV wavelengths of $\lambda \leq 132.6 \mathrm{~nm}$ are found in greater amounts at altitudes above $95 \mathrm{~km}$. They contain energy $\geq 902.2 \mathrm{~kJ} / \mathrm{mol}$ and are able to abstract two $\mathrm{H}$ atoms from a $\mathrm{CH}_{4}$ molecule in one hit. Even though the pathways of methane photolysis are not yet exactly known, it can be deduced that photolysis prevents the existence of appreciable $\mathrm{CH}_{4}$ above $100 \mathrm{~km}$.

\subsection{Destruction of $\mathrm{H}_{2} \mathrm{O}_{(\mathrm{g})}$}

\subsection{Abstraction of $\mathrm{OH}$ from $\mathrm{H}_{2} \mathrm{O}_{(\mathrm{g})}$ by photolysis}

The $\mathrm{O}-\mathrm{H}$ bond dissociation energy in $\mathrm{H}_{2} \mathrm{O}, \mathrm{D}_{0}(\mathrm{H}-\mathrm{OH})$ is $492 \mathrm{~kJ} / \mathrm{mol}$. The second bond dissociation energy, $\mathrm{D}_{0}(\mathrm{O}$ - $\mathrm{H}$ ), is $425.8 \mathrm{~kJ} / \mathrm{mol}$. The enthalpy for atomization of water is equivalent to the sum of the two successive gas-phase $\mathrm{O}-\mathrm{H}$ bond dissociation energies in water, $\Delta \mathrm{H}_{\text {atomiz }}\left(\mathrm{H}_{2} \mathrm{O}\right) \equiv \mathrm{D}_{0}(\mathrm{H}-\mathrm{OH})+\mathrm{D}_{0}(\mathrm{O}-\mathrm{H})$, yielding 917.8 $\mathrm{kJ} / \mathrm{mol}$ [43].

The absorption spectrum of $\mathrm{H}_{2} \mathrm{O}_{(\mathrm{g})}$ in the VUV region exhibits two broad features that peak at about $165 \mathrm{~nm}$ and $128 \mathrm{~nm}$ [41]. The VUV absorption cross section at 121.6 and $160.8 \mathrm{~nm}$ are $13.6 \times 10^{-18} \mathrm{~cm}^{2}$ and $4.1 \times 10^{-18} \mathrm{~cm}^{2}$ molecule $^{-1}$. At the wavelength of $185 \mathrm{~nm}$ the UV absorption cross section of $\mathrm{H}_{2} \mathrm{O}$ is $6.78 \times 10^{-20} \mathrm{~cm}^{2}$ molecule $^{-1}$ [44]. At wavelengths between 185 and $193 \mathrm{~nm}$ the cross section decreases in a logarithmic fashion at about $5 \%$ per Angstrom $(0.1 \mathrm{~nm})$ [45].

UV wavelengths where $\lambda<193 \mathrm{~nm}$ contain energy $>619.8 \mathrm{~kJ} / \mathrm{mol}$. In photolysis there is enough energy for the abstraction of $\mathrm{OH}$ from the $\mathrm{H}_{2} \mathrm{O}$ molecule. The limiting factor is the small absorption coefficient. As seen from Figure 4 some $\mathrm{H}_{2} \mathrm{O}$ is photolyzed already at an altitude of $65 \mathrm{~km}$. Around this altitude, the cut-off of UV photons is $185 \geq \lambda \geq 193 \mathrm{~nm}$.

In the daytime, above $95 \mathrm{~km}$ there are no hydroxyl emissions (see Figure 4). Subsequently, this altitude receives UV radiation with wavelengths of $\leq 130.4 \mathrm{~nm}$, photons of which contain energy $\geq 917.8 \mathrm{~kJ} / \mathrm{mol}$. They can directly atomize water according to reaction (4). Then there is no hydroxyl phase, and subsequently no $\mathrm{OH}$ relaxation emissions to be observed.

$$
\mathrm{H}_{2} \mathrm{O}+\mathrm{h} v(\lambda \leq 130.4 \mathrm{~nm}) \rightarrow \mathrm{H}_{2}+1 / 2 \mathrm{O}_{2} .
$$

The most intensive $\mathrm{OH}$ emission takes place between the altitudes of 83 to $90 \mathrm{~km}$ (see Figure 4). Therefore, below 90 $\mathrm{km}$ there is very little UV radiation $\lambda \leq 130.4 \mathrm{~nm}$.

\subsubsection{Abstraction of $\mathrm{OH}$ from $\mathrm{H}_{2} \mathrm{O}_{(\mathrm{g})}$ by chemical reactions}

During the night, in the absence of photolysis, excited $\mathrm{O}\left({ }^{1} \mathrm{D}\right)$ atoms abstract hydroxyl from the water molecule (reaction 5) [46]. Isotopic experiments show that two hydroxyls are formed, and that the reaction (5) proceeds exothermic [40]:

$$
{ }^{16} \mathrm{O}\left({ }^{1} \mathrm{D}\right)+\mathrm{H}_{2}{ }^{18} \mathrm{O} \rightarrow{ }^{16} \mathrm{OH}+{ }^{18} \mathrm{OH} ; \Delta \mathrm{H}^{\circ}=-118 \mathrm{~kJ} / \mathrm{mol} \text {. }
$$

An important source of the $\mathrm{O}\left({ }^{1} \mathrm{D}\right)$ is the relaxation of $\mathrm{O}\left({ }^{1} \mathrm{~S}\right)$ to $\mathrm{O}\left({ }^{1} \mathrm{D}\right)$ which takes place a few kilometers above in the MLT ozone layer, causing there the green nightglow which continues the whole night. Due to its relatively long lifetime $O\left({ }^{1} D\right)$ is able to enter the mesopause for the reaction with water vapor. During the ablation of meteorites hot metal is abstracting $\mathrm{O}$ from $\mathrm{O}_{2}$. Then $\mathrm{O}\left({ }^{1} \mathrm{~S}\right)$ and $\mathrm{O}\left({ }^{1} \mathrm{D}\right)$ are produced as well (see sections 3.4.2 and 3.6.1).

If an electronically or vibrationally excited oxygen molecule has a minimum energy content of $190 \mathrm{~kJ} / \mathrm{mol}$, and if it reacts further with the $\mathrm{O}\left({ }^{3} \mathrm{P}\right)$ atom, an $\mathrm{O}\left({ }^{1} \mathrm{D}\right)$ atom is produced (reaction 6):

$$
\begin{gathered}
\mathrm{O}\left({ }^{3} \mathrm{P}\right)+\mathrm{O}_{2}\left(\mathrm{X}^{3} \Sigma_{\mathrm{g}}^{-}, v>11\right) \text { or } \mathrm{O}_{2}\left({ }^{1} \Delta_{\mathrm{g}}, v>5\right) \\
\text { or } \mathrm{O}_{2}\left(\mathrm{~b}^{1} \Sigma_{\mathrm{g}}^{+}, v>2\right) \rightarrow \mathrm{O}\left({ }^{1} \mathrm{D}\right)+\mathrm{O}_{2}\left(\mathrm{X}^{3} \Sigma_{\mathrm{g}}{ }^{-}\right) .(6)
\end{gathered}
$$


(a) Nighttime

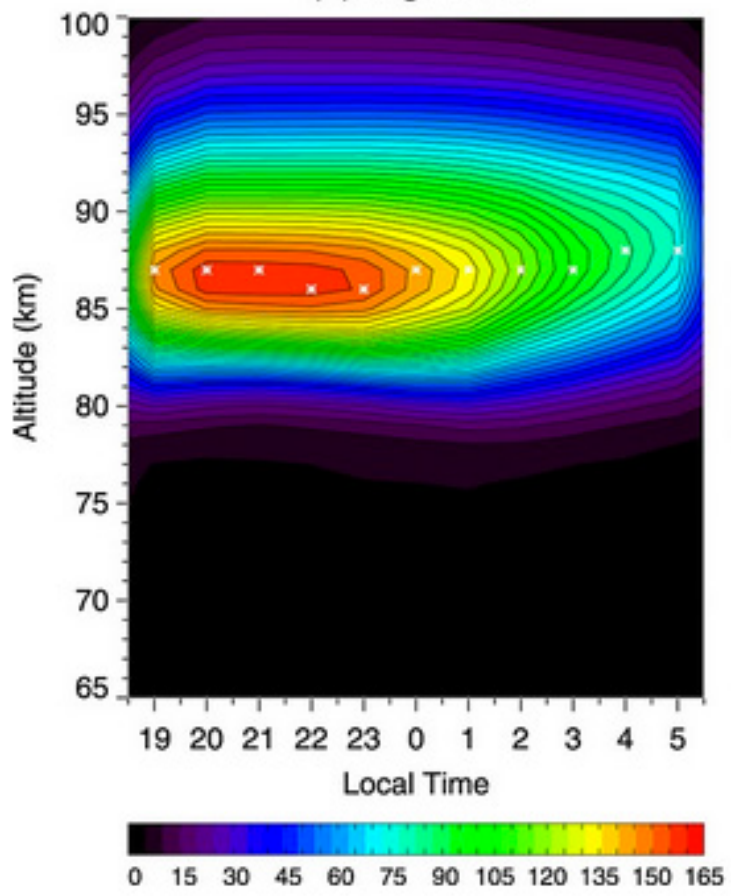

(b) Daytime

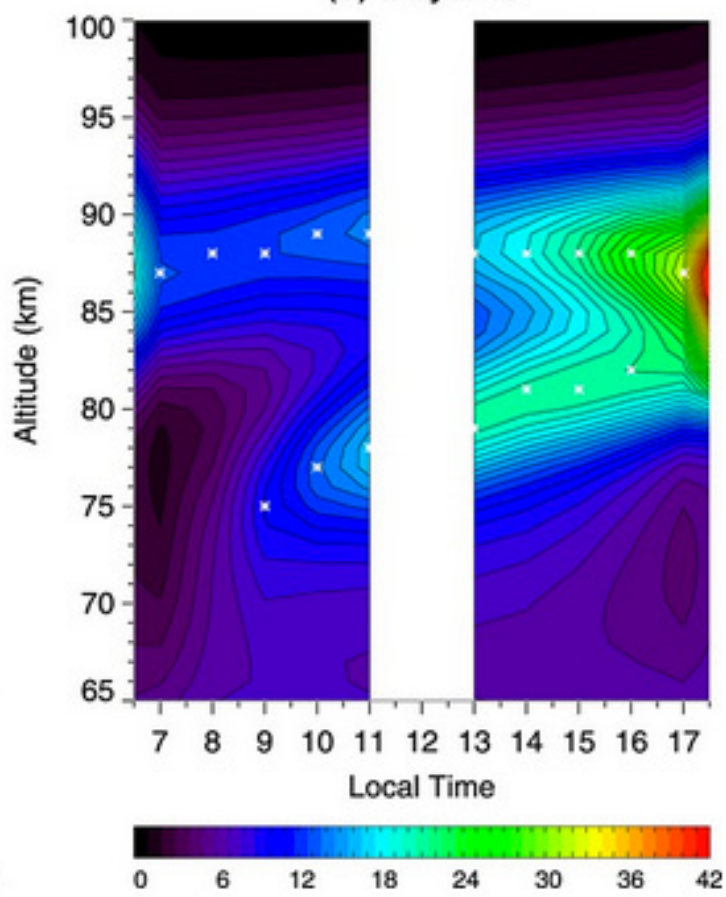

Figure 4. Local time distributions of 12-year mean $\mathrm{OH}$ glow of Meinel band (a) nightglow and (b) dayglow emission layers at the equator from SABER observations at $2.0 \mu \mathrm{m}$. The unit for emission rate is in $10^{3}$ photons $\mathrm{cm}^{-3} \mathrm{~s}^{-1}$ [47].

If excited oxygen molecules have more energy than $296.2 \mathrm{~kJ} / \mathrm{mol}$, they are also able to react with $\mathrm{H}_{2} \mathrm{O}_{(\mathrm{g})}$ to form $\mathrm{OH}$ and $\mathrm{HO}_{2}$. In the atmosphere the reaction then becomes exothermic and spontaneous [46]. Excited oxygen molecules $\mathrm{O}_{2}\left(\mathrm{c}^{1} \Sigma_{u}^{-}\right), \mathrm{O}_{2}\left(\mathrm{~A}^{11} \Delta_{u}\right)$ and $\mathrm{O}_{2}\left(\mathrm{~A}^{3} \Sigma_{u}^{+}\right)$have energy in the range of 408.8 to $492.4 \mathrm{~kJ} / \mathrm{mol}$ and vibrationally highly excited ground state $\mathrm{O}_{2}\left(\mathrm{X}^{3} \Sigma_{\mathrm{g}}^{-}, v \geq 26\right)$ molecules have an energy content of $405 \mathrm{~kJ} / \mathrm{mol}$ (see Table 1 and reactions 7 and 8 ):

$$
\begin{array}{r}
\mathrm{H}_{2} \mathrm{O}+\mathrm{O}_{2}\left(\mathrm{~A}^{3} \Sigma_{u}{ }^{+}\right) \rightarrow \mathrm{HO}_{2}+\mathrm{OH} \\
\mathrm{H}_{2} \mathrm{O}+\mathrm{O}_{2}\left(\mathrm{X}^{3} \Sigma_{\mathrm{g}}^{-}, v \geq 26\right) \rightarrow \mathrm{HO}_{2}+\mathrm{OH}^{*} .
\end{array}
$$

$\mathrm{HO}_{2}$ reacts further with oxygen atoms, forming excited $\mathrm{OH}^{*}$. This reaction is exothermic by about $226 \mathrm{~kJ} / \mathrm{mol}$ [46], so a vibrationally excited ground state or electronically excited oxygen molecule forms as well (reactions 9 and 10):

$$
\begin{array}{r}
\mathrm{HO}_{2}+\mathrm{O}\left({ }^{3} \mathrm{P}\right) \rightarrow \mathrm{OH}^{*}+\mathrm{O}_{2}\left(\mathrm{X}^{3} \Sigma_{\mathrm{g}}^{-}, v>1\right) \\
\mathrm{HO}_{2}+\mathrm{O}\left({ }^{3} \mathrm{P}\right) \rightarrow \mathrm{OH}^{*}+\mathrm{O}_{2}\left({ }^{1} \Delta_{\mathrm{g}}\right) \text { or } \mathrm{O}_{2}\left(\mathrm{~b}^{1} \Sigma_{\mathrm{g}}^{+}\right) .
\end{array}
$$

Gao et al. [47] have mapped a 12-year mean distribution of $\mathrm{OH}$ dayglow and nightglow (see Figure 4). The reactions (5-10) maintain a high content of excited hydroxyls in the mesopause during the night, until the ascent of $\mathrm{H}_{2} \mathrm{O}_{(\mathrm{g})}$ from an altitude of 70 to $75 \mathrm{~km}$ starts to decrease and the descent of ice from an altitude of 81 to $83 \mathrm{~km}$ starts to increase.

\subsection{Ecological Significance of the Atomizing of Water by Photodissociation}

\subsubsection{Amount of $\mathrm{O}_{2}$ Produced Annually by Photodissociation of Water in the Atmosphere}

At present, $4.8 \times 10^{11} \mathrm{ga}^{-1}$ of water is photolyzed in the upper atmosphere into its constituent gases. $\mathrm{O}_{2}$ stays in the atmosphere and the $\mathrm{H}_{2}$ (as $\mathrm{H}$ atom) escapes into space [48]. Compared to the present volume of the ocean water $\left(1.335 \times 10^{9} \mathrm{~km}^{3}\right)$ on Earth, $4.8 \times 10^{11} \mathrm{~g}$ or $4.8 \times 10^{-4} \mathrm{~km}^{3}$ is an insignificant amount. However, in the case of atmospheric phenomenon, it would be more appropriate to compare gas volumes than liquid volumes. For that purpose, the amount water photolyzed annually needs to be converted into moles of $\mathrm{O}_{2}$ by basic chemistry calculus.

According to the reaction (4), one mole of water yields half a mole of $\mathrm{O}_{2}$. Annually, $2.67 \times 10^{10} \mathrm{~mol}(\mathrm{NTP})$ of water is photolyzed, and $1 / 2 \times 2.67 \times 10^{10}=1.33 \times 10^{10} \mathrm{~mol}$ of $\mathrm{O}_{2}$ gas is formed. Multiplying by the molar mass of $\mathrm{O}_{2}(32 \mathrm{~g})$ gives $4.256 \times 10^{11} \mathrm{~g}$ of $\mathrm{O}_{2}$. The total mass of the atmosphere $\left(5.136 \times 10^{21} \mathrm{~g}\right)$ contains $20.9 \%$ or $1.073 \times 10^{21} \mathrm{~g}$ of $\mathrm{O}_{2}$ [49]. Dividing $1.073 \times 10^{21} \mathrm{~g}$ by $4.256 \times 10^{11} \mathrm{ga}^{-1}$ gives $2.5 \times 10^{9} \mathrm{a}$. This means that with the present annual photodissociation rate of water the present atmospheric level (PAL) of $\mathrm{O}_{2}$ would have been produced during the first 2.5 billion years of Earth's existence. 


\subsubsection{Reaction of Hot Iron with Water Vapor}

Walker [48] has described the evolution of Earth as follows: "It is hardly likely that Earth formed with crust, oceans and atmosphere already in place. It is more likely that there was a period, after the formation of the Earth, when these features were accumulating and evolving, presumably as a result of gravitational differentiation of the material of the primitive Earth."

During the primitive phase of Earth, the surface temperature may have been as high as $2000 \mathrm{~K}$, and the crust temperature even higher. The main reasons for this difference are the gravitational potential energy released upon core formation. Radioactivity could also contribute to the heating of Earth early in its evolution if significant amounts of certain extinct radionuclides (e.g., Aluminum 26) were incorporated into the accreting Earth [50]. Meteorites and oxidation of iron have contributed to the surface temperature as well.

Walker [48] estimates that one sixth of the ocean volume would have been needed to produce all the iron oxides now in the top $50 \mathrm{~km}$ of the crust. Most of the oxidation has taken place inside the crust, so there needs to be a mechanism that was producing oxygen atoms there.

Unfortunately, the most striking example of the power of the reaction of hot metal with steam is provided by the Fukushima Daiichi Nuclear Power Plant accident in 2011. The nuclear fuel at Fukushima was composed of uranium oxide pellets encased in a zirconium cladding. Due to the lack of fresh cooling water, the fuel rods created high temperatures that continually boiled water into steam. Once the rods reached more than $1200^{\circ} \mathrm{C}$, the zirconium started to interact with the steam and abstract the oxygen atom from the $\mathrm{H}_{2} \mathrm{O}_{(\mathrm{g})}$ (reaction 11). The pressure relief valves were not operational either. If the concentration of $\mathrm{H}_{2}$ exceeds $4 \%$ in the air, a spark will initiate a violent chain reaction. At Fukushima, that happened three times in five days in the air of the power plant, and three separate hydrogen explosions occurred [51].

$$
\mathrm{Zr}+2 \mathrm{H} 2 \mathrm{O} \rightarrow \mathrm{ZrO} 2+2 \mathrm{H} 2+\Delta \mathrm{H}^{\circ} .
$$

One kilogram of $\mathrm{Zr}$ produces $0.0442 \mathrm{~kg}$ of $\mathrm{H}_{2}$. Reaction (11) is highly exothermic: $\Delta \mathrm{H}=-586.6 \mathrm{~kJ} / \mathrm{mol}$ [52].

In the hot crust of the Precambrian Earth, iron abstracted oxygen atom from $\mathrm{H}_{2} \mathrm{O}(\mathrm{g})$. Ferrous and ferric (haematite) oxides, and magnetite $\left(\mathrm{Fe}_{3} \mathrm{O}_{4}\right)$ was formed and $\mathrm{H}_{2}$ gas was liberated (reactions (12-14).

$$
\begin{gathered}
\mathrm{Fe}+\mathrm{H}_{2} \mathrm{O} \rightarrow \mathrm{FeO}+\mathrm{H}_{2} \\
2 \mathrm{Fe}+3 \mathrm{H} 2 \mathrm{O} \rightarrow \mathrm{Fe} 2 \mathrm{O} 3+3 \mathrm{H} 2 \\
3 \mathrm{Fe}+4 \mathrm{H} 2 \mathrm{O} \rightarrow \mathrm{Fe} 3 \mathrm{O} 4+4 \mathrm{H} 2 .
\end{gathered}
$$

The formation enthalpy of crystalline $\mathrm{Fe}_{3} \mathrm{O}_{4}$, determined according to (reaction 14), is $-1115 \mathrm{~kJ} / \mathrm{mol}$ [53]. The exothermic reactions (12-14) have, in part, kept the crust temperature high.

\subsubsection{Intensity of $\mathrm{H}_{2} \mathrm{O}_{(\mathrm{g})}$ photodissociation during the steam atmosphere period}

It is likely that Earth has had an atmosphere composed of
$\mathrm{N}_{2}$ molecules from its beginning. It is highly unlikely that all gaseous $\mathrm{N}_{2}$ would have been buried in the crust and the mantle during the aggregate phase of Earth. Some was clearly buried then because even these days $\mathrm{N}_{2}$ gas is still emitted during volcanic eruptions.

The most important gas in volcanic emissions is water vapor. Other gases include $\mathrm{H}_{2}, \mathrm{CO}, \mathrm{N}_{2}$ and $\mathrm{CO}_{2}$ [32]. As the temperature of the $\mathrm{H}_{2} \mathrm{O}_{(\mathrm{g})}$ exhaled from the crust was about $2000 \mathrm{~K}$, a layer of steam atmosphere was created. It was a combination of $\mathrm{H}_{2} \mathrm{O}_{(\mathrm{g})}$ in the form of superheated and saturated steam [54]. Its height may have been kilometers from the ground. During the steam atmosphere phase, liquid water could not descend to the surface.

Most meteorites formed within a period of less than $1 \times 10^{8}$ years at about 4.5 to $4.6 \times 10^{9}$ years ago [55]. Yet the most intensive period can actually be narrowed to between 4.57 and $4.54 \times 10^{9}$ years ago [32]. The meteorite bombardment was also likely to have been at its most intensive then as well. Heat generated by friction heated the steam layer from above, and the impacts of the meteorites with the ground heated the crust and provided non-oxidized iron as well. These may have been important additional energy sources for maintaining the surface temperature and the steam atmosphere.

On present-day Venus, at an altitude of $80 \mathrm{~km}$, the atmospheric night-side temperature is $190 \mathrm{~K}$ [56]. This closely corresponds to the present-day cold trap temperature in the tropical tropopause of Earth.

In Venus the high-surface temperature is transferred upwards via conduction and radiation. In addition to conduction and radiation, on the Precambrian Earth the high surface temperature has been moved upwards with convection via ascending water vapors as well.

As the surface of Earth has been much hotter than that of Venus is now, it is plausible to presume that the first cold trap temperature of $190 \mathrm{~K}$ on Earth might have been above the altitude of $95 \mathrm{~km}$, if there then even was any cold trap (for ice formation) at all. During the steam atmosphere period amount of photodissociated $\mathrm{H}_{2} \mathrm{O}_{(\mathrm{g})}$ equaled that $\mathrm{H}_{2} \mathrm{O}_{(\mathrm{g})}$ which was exhaled from the crust into the atmosphere. Production of $\mathrm{O}_{2}$ may have been very effective. Non-oxidized iron and other non-oxidized metals on the surface as well as metals from the ablation of meteoroids consumed atmospheric oxygen by abstracting $\mathrm{O}$ from $\mathrm{O}_{2}$. These processes were preventing the atmospheric $\mathrm{O}_{2}$ concentration to increase excessively.

A mix of hydrogen and (ground state) oxygen molecules in the atmosphere does not react. This is because the speed of the molecules does not provide enough kinetic energy to activate the reaction during collisions between the reactants.

Hydrogen molecules formed in the crust may have mostly reacted 1) with metals forming hydrides and hydroxides and also 2) with graphite forming methane [57].

Hydrogen molecules formed by photodissociation of water above the $95 \mathrm{~km}$ altitude have ascended further while oxygen molecules have distributed into the lower 
atmosphere. Therefore, the concentration of hydrogen has hardly reached the critical $4 \%$ limit in the lower atmosphere. We can therefore conclude that the $\mathrm{O}_{2}$ molecules generated by photodissociation of $\mathrm{H}_{2} \mathrm{O}_{(\mathrm{g})}$ were not consumed by hydrogen.

Recent findings show that solar wind picks up $\mathrm{O}$ ions from the upper thermosphere. When Earth is between the sun and the moon, these ions are then carried to the moon [58]. When the $\mathrm{H}_{2}$ molecules ascend high enough, they meet UV photons at the wavelength of the Lyman $\alpha$ line and are dissociated into $\mathrm{H}$ atoms, which ascend further and are eventually stripped off by the solar wind.

When the peak intensity of the meteorite bombardment subsided, most of the iron in the crust was probably oxidized as well. Due to the loss of energy the steam layer began falling. Eventually there was no longer enough energy to maintain the superheated steam layer at all. Tropospheric and mesospheric cold traps were created. Liquid water started to descend to the surface, thereby cooling it. Once the era of the intensive meteorite bombardment ended, an oxidative atmosphere had already developed.

\subsubsection{Ecological Significance of the Reaction of $\mathrm{H}_{2}$ with Graphite in the Core}

Considering that approximately one sixth of the ocean volume of $\mathrm{H}_{2} \mathrm{O}_{(\mathrm{g})}$ was consumed in the top $50 \mathrm{~km}$ of the crust during the steam atmosphere phase, reaction of hydrogen molecules with graphite (15) may have contributed importantly to our natural gas reserves.

$$
\mathrm{C}+2 \mathrm{H}_{2} \rightarrow \mathrm{CH}_{4}
$$

One sixth of the ocean volume is $0.2225 \times 10^{9} \mathrm{~km}^{3}$, containing $0.2225 \times 10^{21} \mathrm{~kg}$ of $\mathrm{H}_{2} \mathrm{O}$. In moles it is $0.2225 \times 10^{24} \mathrm{~g} / 18 \mathrm{~g} / \mathrm{mol}=1.24 \times 10^{22}$ mol. According to reaction (4) the number of hydrogen molecules is also 1.24 $\times 10^{22} \mathrm{~mol}$. As two moles of $\mathrm{H}_{2}$ yields one mole of methane (reaction 15), this would result in $0.62 \times 10^{22} \mathrm{~mol}$ of methane. Because one mole of methane gas (in NTP conditions) is $22.4 \mathrm{~L}$, methane would have produced $1.39 \times 10^{23} \mathrm{~L}$ or $1.39 \times 10^{20} \mathrm{~m}^{3}$.

In 2017 global natural gas reserves were estimated to be $1.935 \times 10^{14} \mathrm{~m}^{3}$ [59]. Even if the efficiency of the reaction (15) would have been only one per mil, more than 700 times than the present estimated natural gas reserves would have been produced. It is likely that deeper in the crust there remains plenty of (so far) unobservable natural gas sources.

\subsection{The Middle Mesospheric Maximum of Ozone (MMM)}

\subsubsection{Geographical Location of the MMM Layer}

In the CRISTA measurements [17] all profiles show increasing ozone mixing ratios above $80 \mathrm{~km}$, in the lower part of the MLT. Below this altitude, a distinct ozone layer (MMM) exists centered at $72.5 \mathrm{~km}$ in the high-latitude profile. The equatorial (2S) and mid-latitude (30S) profiles are rather similar but without the MMM layer (see Figure $5)$.

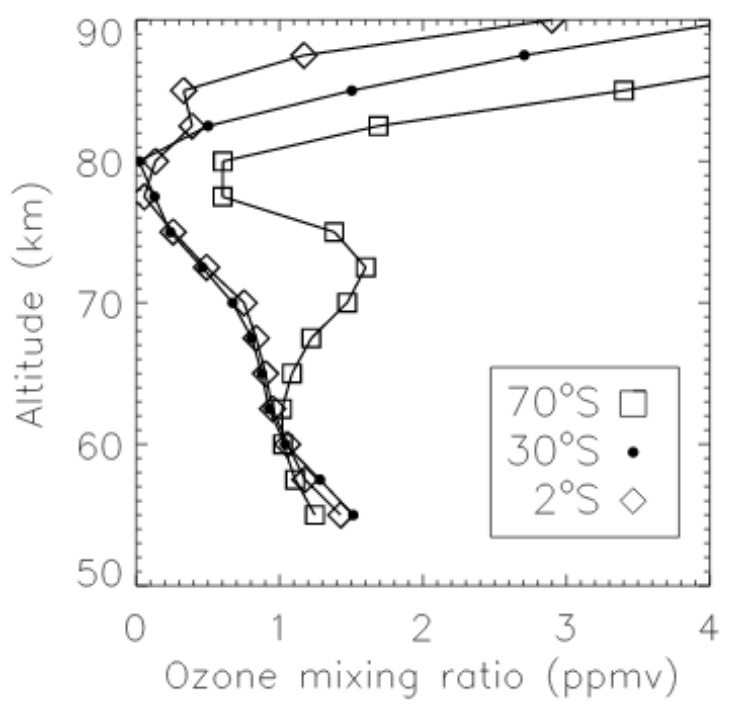

Figure 5. Results of CRISTA 2 observations show mesospheric ozone mixing ratio (ppmv) between the latitudes of $2^{\circ} \mathrm{S}$ to $70^{\circ} \mathrm{S}$. Data are averages of profiles taken between August 13 and 15, 1997. Local times are approximately 0000,0400 and 0500 hours for $70^{\circ} \mathrm{S}, 30^{\circ} \mathrm{S}$ and $2^{\circ} \mathrm{S}$ respectively [17].

Moreira et al. [60] studied the annual variation in mesospheric ozone above Bern (Switzerland, 46.95N, 7.44E). The winter enhancement of nighttime mesospheric ozone was observed, indicating that the MMM layer during winter reaches northern mid-latitudes as well. This effect is smaller in amplitude at mid-latitudes than it is at high latitudes.

Rogers et al. [61] studied seasonal and diurnal variations of the MLT ozone near the mesopause from observations of the 11.072-GHz line in Massachusetts $(42.62 \mathrm{~N}, 71.37 \mathrm{~W}$ and $42.61 \mathrm{~N}, 71.49 \mathrm{~W}$ ) on January 26 . The diurnal variation in the concentrations of ozone above $80 \mathrm{~km}$ (in the MLT ozone layer) is clearly characterized by an increase of ozone after sunset and by a decrease before sunrise (see Figure 6). Below $80 \mathrm{~km}$ the same trends can be seen, though they are much weaker. However, it can be deduced that even at $42.62^{\circ} \mathrm{N}$ a winter enhancement of ozone with a very small amplitude exists.

\subsubsection{Formation of the MLT Layer during the Civil and Nautical Twilights after Sunset}

The sunrise at an altitude of $88 \mathrm{~km}$ above Neuchatel (Switzerland $(7 \mathrm{~N}, 7 \mathrm{E})$ is about 50 minutes earlier and sunset about 70 minutes later than at the ground level [62].

In Massachusetts the length of the day on January 26 is 9 h $47 \mathrm{~min}$. Given that in the MLT above Massachusetts the daytime is two hours longer that it is on the ground, the length of the day there is $11 \mathrm{~h} 47 \mathrm{~min}$. The ozone layer is at a stable daytime concentration for about $12 \mathrm{~h} 30 \mathrm{~min}$, including about 15 minutes before sunrise and about 30 minutes after sunset. The increase in ozone concentration 
starts when the civil twilight already has begun (see Figure 6).

Civil twilight is the moment when the sun is below the horizon and the solar elevation angle $\left(\theta_{\mathrm{s}}\right)$ is between $-6^{\circ}<\theta_{\mathrm{s}}<0$. Human observers are, at this time, able to distinguish terrestrial objects. During nautical twilight $\left(-12^{\circ}<\theta_{\mathrm{s}}<-6\right)$, however, only outlines of objects are visible to a human observer [63].

In Massachusetts on January 26, the $\theta_{\mathrm{s}}$ was $27.56^{\circ}$ [64]. In the MLT layer, the amount of time from 1200 hours to sunset is 353 minutes. A decrease in $\theta_{\mathrm{s}}$ by one degree takes $12 \mathrm{~min} .54 \mathrm{~s}$. The duration of the civil twilight is $1 \mathrm{~h} 17 \mathrm{~min}$. The maximum ozone concentration is reached around 2000 hours when nautical twilight time has begun (see Figure 6).

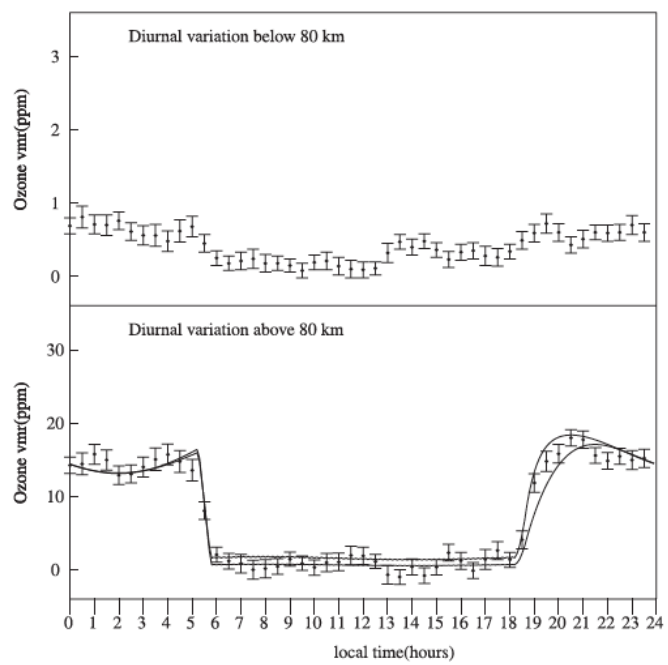

Figure 6. Diurnal variations in the ozone VMR for regions above $80 \mathrm{~km}$ $\left(42.62^{\circ} \mathrm{N}, 71.37^{\circ} \mathrm{W}\right)$ from observations at $11 \mathrm{GHz}$ on January 262008 [61].

\subsubsection{Formation of the MMM Layer during the Civil and Nautical Twilights after Sunset}

On the ground level in mid-August at $70^{\circ} \mathrm{S}$, the length of the day is $5 \mathrm{~h} 10 \mathrm{~min}$, and subsequently in the MMM layer it is about $7 \mathrm{~h}$ hours. The time from noon to sunset in the MMM layer is so about 210 minutes. At noon, the $\theta_{\mathrm{s}}$ on the ground is 6.25 . It decreases one degree in about 33 minutes.

In Bern on February 15, the length of the day is about 10 h $30 \mathrm{~min}$, and in the MMM layer it is about $13 \mathrm{~h} 24 \mathrm{~min}$. The time from noon to sunset is 402 minutes. On the ground at noon, the $\theta_{\mathrm{s}}$ is 26 , and it decreases one degree in about 15 minutes 30 seconds.

In the northern mid-latitudes, $\theta_{\mathrm{s}}$ decreases two times faster than in the latitudes around the Arctic circle. This means that during the civil and nautical twilight the sun's rays have twice as much time to affect.

When the increase in ozone concentration starts, all UV radiation and visible radiation in the short range are already cut-off. The turnover rate of ozone molecules then decreases. As the wavelengths of the sun's rays further increase, the ozone concentration increases and reaches its maximum during the nautical twilight.

The duration of civil and nautical twilights increases the further north one moves. IR photons therefore have more time to affect $\mathrm{O}_{2}$ and $\mathrm{O}_{3}$ molecules. This is obviously important for the formation of the maximum intensity of the MMM layer. In the Northern Hemisphere it restricts the layer's location to between the northern mid-latitudes and somewhat north from the Arctic Circle, and its existence to between the winter months of November to February. In the Southern Hemisphere the layer's location is between the southern mid-latitudes and south from the Antarctic Circle and its existence to between the winter months of May to August.

\subsubsection{Role of Excited Triplet State $\mathrm{O}_{3}$ Molecules in the Formation of the MMM Layer}

Like oxygen molecules, ozone also has several vibrationally and electronically excited states. The three lowest transition vibrational energy levels of ${ }^{16} \mathrm{O}_{3}$ are 13.2 $\mathrm{kJ} / \mathrm{mol}, 8.4 \mathrm{~kJ} / \mathrm{mol}$ and $12.5 \mathrm{~kJ} / \mathrm{mol}$ for the symmetric stretch, bending, and antisymmetric stretch modes, respectively [65]. The vertical excitation energy of the triplet states ${ }^{3} \mathrm{~B}_{2},{ }^{3} \mathrm{~B}_{1}$, and ${ }^{3} \mathrm{~A}_{2}$ are $98.4,156.3$ and 170.8 $\mathrm{kJ} / \mathrm{mol}$ respectively [66].

Ozone has distinct IR absorption between the wavelengths of 750 and $1060 \mathrm{~nm}$ (the Wulf band area) [67]. The energies corresponding to these wavelengths are 159.5 to $112.9 \mathrm{~kJ} / \mathrm{mol}$.

The existence of distinct absorption spectra actually shows that after the photoexcitation by IR photons, the triplet ozone molecule does not immediately fall apart. The radiative lifetimes $(\tau)$ of the ${ }^{3} \mathrm{~B}_{2},{ }^{3} \mathrm{~A}_{2}$ and ${ }^{3} \mathrm{~B}_{1}$ states of ozone are $83.1 \mathrm{sec}, 0.038 \mathrm{sec}$ and $0.200 \mathrm{sec}$, respectively [66]. Later in the text these triplet ozone molecules are described by the symbol $\mathrm{O}_{3} *$.

\subsubsection{Excited $\mathrm{O}_{2}\left({ }^{1} \Delta_{g}\right)$ and $\mathrm{O}_{2}\left(\mathrm{~b}^{1} \Sigma_{g}{ }^{+}\right)$Molecules}

Oxygen molecules absorb IR photons at $1269 \mathrm{~nm}$ and $1065 \mathrm{~nm}$ [68]. Then $\mathrm{O}_{2}\left(\mathrm{a}^{1} \Delta_{g}, v=0\right)$ and $\mathrm{O}_{2}\left(\mathrm{a}^{1} \Delta_{g}, v=1\right)$ molecules are photoexcited. Their energy content is 94.3 $\mathrm{kJ} / \mathrm{mol}$ and $112.3 \mathrm{~kJ} / \mathrm{mol}$ respectively (see Table 1 ).

At an altitude of $90 \mathrm{~km}$, peak density for ozone is about $1 \times 10^{8}$ and for $\mathrm{O}_{2}\left({ }^{1} \Delta_{\mathrm{g}}\right)$ it is about $3 \times 10^{9} / \mathrm{cm}^{3}$ [69]. During the civil and nautical twilight, the proportion of IR light in the incident sun's rays increases in the MMM layer. This would favor the formation of $\mathrm{O}_{2}\left({ }^{1} \Delta_{g}\right)$. The potential for $\mathrm{O}_{2}\left({ }^{1} \Delta_{g}\right)$ formation can then be considered greater than during the daytime. Due to the long lifetime of $\mathrm{O}_{2}\left({ }^{1} \Delta_{g}\right)$, its concentration most likely exceeds that of the ozone in the MMM layer as well.

The oxygen molecules absorb IR light in the range of 758 to $772 \mathrm{~nm}$, and visible light in the ranges of 685 to 697 $\mathrm{nm}$ and 627 to $637 \mathrm{~nm}$ as well [70]. Then photoexcitation of $\mathrm{O}_{2}\left(\mathrm{~b}^{1} \Sigma_{g}^{+}, \mathrm{v}=0,1\right.$ and 2$)$ occurs. They have energies of $157,173.8$ and $190 \mathrm{~kJ} / \mathrm{mol}$, respectively (see Table 1). 
Table 1. Electronic and vibrational energies $(\mathrm{kJ} / \mathrm{mol})$ of $\mathrm{O}_{2}\left(\mathrm{X}^{3} \Sigma_{\mathrm{g}}^{-}\right), \mathrm{O}_{2}\left(\mathrm{a}^{1} \Delta_{\mathrm{g}}\right), \mathrm{O}_{2}\left(\mathrm{~b}^{1} \Sigma_{\mathrm{g}}^{+}\right), \mathrm{O}_{2}\left(\mathrm{~A}^{\prime 1} \Delta_{\mathrm{u}}\right), \mathrm{O}_{2}\left(\mathrm{~A}^{1} \Delta_{\mathrm{u}}\right), \mathrm{O}_{2}\left(\mathrm{~A}^{3} \Sigma_{\mathrm{u}}^{+}\right)$and $\mathrm{O}_{2}\left(\mathrm{~B}^{3} \Sigma_{\mathrm{u}}^{-}\right)$molecules [71], [72].

\begin{tabular}{|c|c|c|c|c|c|}
\hline \multicolumn{6}{|c|}{$\mathrm{E}_{\mathrm{el}}+\mathrm{E}_{(\mathrm{v})}(\mathrm{kJ} / \mathrm{mol})$} \\
\hline $\mathrm{O}_{2}\left(\mathrm{X}^{3} \Sigma_{\mathrm{g}}^{-}\right)$ & $\mathrm{O}_{2}\left(\mathrm{a}^{1} \Delta_{\mathrm{g}}\right)$ & $\mathrm{O}_{2}\left(\mathrm{~b}^{1} \Sigma_{\mathrm{g}}^{+}\right)$ & $\mathrm{O}_{2}\left(\mathrm{c}^{1} \Sigma_{\mathrm{u}}^{-}\right)$ & $\mathrm{O}_{2}\left(\mathrm{~A}^{\prime 1} \Delta_{\mathrm{u}}\right)$ & $\mathrm{O}_{2}\left(\mathrm{~A}^{3} \Sigma_{\mathrm{u}}^{+}\right)$ \\
\hline $\begin{array}{c}v(0)=0 \\
v(1)=18.6 \\
v(2)=36.9 \\
v(3)=55.0 \\
v(4)=72.8 \\
v(5)=90.3 \\
v(6)=107.5 \\
v(7)=124.5 \\
v(8)=141.2 \\
v(9)=157.6 \\
v(10)=173.8 \\
v(11)=189.7 \\
v(12)=205.3 \\
v(13)=220.6 \\
v(14)=238.9 \\
v(17)=292.9 * * \\
v(26)=405\end{array}$ & $\begin{array}{c}v(0)=94.3 \\
v(1)=112.3 \\
v(2)=129.6 \\
v(3)=146.7 \\
v(4)=163.5 \\
v(5)=180.0 \\
v(6)=196.2 \\
v(7)=212.1 \\
v(8)=227.6 \\
v(9)=242.8 \\
v(10)=257.6\end{array}$ & $\begin{array}{l}v(0)=157.0 \\
v(1)=173.8 \\
v(2)=190.3 \\
v(3)=206.4 \\
v(4)=222.2 \\
v(5)=237.7 \\
v(6)=252.8 \\
v(7)=267.6\end{array}$ & $\begin{array}{l}v(0)=390.8 \\
v(1)=400.1 \\
v(2)=408.9 \\
v(3)=417.2 \\
v(4)=425.6 \\
v(5)=433.3 \\
v(6)=440.7 \\
v(7)=447.6 \\
v(8)=454.2 \\
v(9)=460.2 \\
v(10)=465.8 \\
v(11)=471.0 \\
v(12)=475.6 \\
v(13)=479.7 \\
v(14)=483.3 \\
v(15)=486.4 \\
v(16)=488.9 \\
v(17)=490.7 \\
v(18)=492.2 \\
v(19)=492.9\end{array}$ & $\begin{aligned} v(0) & =413.2^{*} \\
v(1) & =422.6^{*} \\
v(2) & =431.7 \\
v(3) & =440.4 \\
v(4) & =448.7 \\
v(5) & =456.6 \\
v(6) & =463.9 \\
v(7) & =470.7 \\
v(8) & =476.8 \\
v(9) & =482.3 \\
v(10) & =486.8 \\
v(11) & =490.4\end{aligned}$ & $\begin{array}{l}v(0)=418.9 \\
v(1)=428.2 \\
v(2)=437.1 \\
v(3)=445.6 \\
v(4)=453.7 \\
v(5)=461.3 \\
v(6)=468.4 \\
v(7)=474.9 \\
v(8)=480.7 \\
v(9)=485.7 \\
v(10)=489.7 \\
v(11)=492.5\end{array}$ \\
\hline
\end{tabular}

*calculated [71]; [73].

During the civil twilight, $\mathrm{O}_{2}\left(\mathrm{~b}^{1} \Sigma_{g}^{+}\right)$is able to form by photoexcitation. Wayne [74] suggested that $\mathrm{O}_{2}\left(\mathrm{~b}^{1} \Sigma_{g}^{+}\right)$is formed in the energy-pooling process of two $\mathrm{O}_{2}\left({ }^{1} \Delta_{g}\right)$ as well. Then $\mathrm{O}_{2}\left(\mathrm{~b}^{1} \Sigma^{+} \mathrm{g}\right)$ is preferentially formed with two quanta of vibrational excitation (reaction 16) [75]:

$\mathrm{O}_{2}\left({ }^{1} \Delta_{g}, v=1\right)+\mathrm{O}_{2}\left({ }^{1} \Delta_{g} v=1\right) \rightarrow \mathrm{O}_{2}\left(\mathrm{~b}^{1} \Sigma_{g}^{+} v=2\right)+\mathrm{O}_{2}\left(\mathrm{X}^{3} \Sigma_{g}^{-}\right)$ $\Delta \mathrm{H}^{0}=-34.3 \mathrm{~kJ} / \mathrm{mol}$

The quenching of $\mathrm{O}\left({ }^{1} \mathrm{D}\right)$ with $\mathrm{O}_{2}\left(\mathrm{X}^{3} \Sigma_{g}^{-}\right)$produces an $\mathrm{O}_{2}\left(\mathrm{~b}^{1} \Sigma^{+}{ }_{\mathrm{g}}\right)$ molecule and an $\mathrm{O}\left({ }^{3} \mathrm{P}\right)$ atom (reaction 17) [76]:

$$
\mathrm{O}\left({ }^{1} \mathrm{D}\right)+\mathrm{O}_{2}\left(\mathrm{X}^{3} \Sigma_{\mathrm{g}}{ }^{-}\right) \rightarrow \mathrm{O}_{2}\left(\mathrm{~b}^{1} \Sigma_{\mathrm{g}}^{+}\right)+\mathrm{O}\left({ }^{3} \mathrm{P}\right)
$$

$\mathrm{O}_{2}\left(\mathrm{~b}^{1} \Sigma_{\mathrm{g}}^{+}\right)$molecules maintain the ozone concentration (reaction 18), as $\mathrm{O}\left({ }^{3} \mathrm{P}\right)$ creates new ozone:

$$
\mathrm{O}_{2}\left(\mathrm{~b}^{1} \Sigma_{\mathrm{g}}^{+}\right)+\mathrm{O}_{3} \rightarrow \mathrm{O}\left({ }^{3} \mathrm{P}\right)+2 \mathrm{O}_{2}\left(\mathrm{X}^{3} \Sigma_{\mathrm{g}}{ }^{-}\right)
$$

3.5.6. Role of excited triplet state $\mathrm{O}_{3}$ and $\mathrm{O}_{2}\left({ }^{1} \Delta_{g}\right)$ molecules in the formation of the MMM layer

During the nautical twilight when the ozone concentration reaches its maximum, the incident solar radiation contains only the Wulf band IR photons. Then only $\mathrm{O}_{3}{ }^{*}$ and $\mathrm{O}_{2}\left({ }^{1} \Delta_{g}\right)$ are able to be photoexcited.

The reaction (19) is endothermic by $12.2 \mathrm{~kJ} / \mathrm{mol}$ if the standard enthalpy $(142.7 \mathrm{~kJ} / \mathrm{mol})$ of ground state ozone $\left(\mathrm{O}_{3}\left({ }^{1} \mathrm{~A}\right)\right)$ is used in the calculation. However, due to the participation of a vibrationally excited ground state ozone molecule it is exothermic [72]:

$$
\mathrm{O}_{2}\left({ }^{1} \Delta_{g}\right)+\mathrm{O}_{3} \rightarrow \mathrm{O}\left({ }^{3} \mathrm{P}\right)+2 \mathrm{O}_{2}\left(\mathrm{X}^{3} \Sigma_{g}^{-}\right)
$$

When $\mathrm{O}_{2}\left(\mathrm{a}^{1} \Delta_{g}, v \geq 1\right)$ reacts with ozone, reaction (19) is exothermic even without the presence of an excited ozone molecule. $\mathrm{O}_{2}\left({ }^{1} \Delta_{g}\right)$ molecules maintain the ozone concentration before the darkness begins.

If not participating in the collision reactions, the $\mathrm{O}_{3}$ * molecule is, due to its great energy content, spontaneously relaxed (reaction 20):

$$
\mathrm{O}_{3}{ }^{*} \rightarrow \mathrm{O}\left({ }^{3} \mathrm{P}\right)+\mathrm{O}_{2}\left(\mathrm{X}^{3} \Sigma_{\mathrm{g}}{ }^{-}\right)
$$

In the reaction of $\mathrm{O}\left({ }^{3} \mathrm{P}\right)$ with ground state ozone, electronically excited $\mathrm{O}_{2}\left({ }^{1} \Delta_{g}\right)$ and vibrationally excited ground state $\mathrm{O}_{2}$ molecules up to 17 quanta are formed (reaction 21) [77]:

$$
\begin{array}{r}
\mathrm{O}_{3}\left({ }^{1} \mathrm{~A}\right)+\mathrm{O}\left({ }^{3} \mathrm{P}\right) \rightarrow \mathrm{O}_{2}\left(\mathrm{X}^{3} \Sigma_{\mathrm{g}}^{-}, v \leq 17\right)+\mathrm{O}_{2}\left({ }^{1} \Delta_{\mathrm{g}}\right) ; \\
\Delta \mathrm{H}^{0}=-5.3 \mathrm{~kJ} / \mathrm{mol}(21)
\end{array}
$$

According to McGrath and Norrish [71], vibrationally excited oxygen molecules having 18 or more quanta are able to react with ozone and form $\mathrm{O}\left({ }^{1} \mathrm{D}\right)$ (reaction 22$)$ :

$$
\mathrm{O}_{2}\left(\mathrm{X}^{3} \Sigma_{\mathrm{g}}^{-}, v \geq 18\right)+\mathrm{O}_{3} \rightarrow 2 \mathrm{O}_{2}\left(\mathrm{X}^{3} \Sigma_{\mathrm{g}}^{-}, v=0\right)+\mathrm{O}\left({ }^{1} \mathrm{D}\right)
$$

Given even the $\tau$ of 0.038 or 0.200 seconds, collisional reactions of $\mathrm{O}_{3}{ }^{*}$ are possible. Their contribution to the reaction (21) would produce $\mathrm{O}_{2}\left(\mathrm{X}^{3} \Sigma_{\mathrm{g}}^{-}, v \geq 18\right)$, which would provide an important additional energy input to induce a small increase in ozone concentration. The ozone concentration drops only slightly during the dark period of the night.

\subsection{Noctilucent clouds}

3.6.1 Meteoric Smoke Particles and the Formation Mechanism of NLCs

Every day, more than 40 tons of meteorites hit Earth [78]. The ablation of meteorites by atmospheric friction produces metal species such as $\mathrm{Fe}, \mathrm{Mg}, \mathrm{Si}, \mathrm{Na}, \mathrm{Ca}$ and $\mathrm{K}$ in the atmosphere. Their atomic radiuses range from 111 to $243 \mathrm{pm}$. 
Ablation causes meteors to glow. If the direction of motion of the meteoroid is opposite to that of Earth, the speed of encounter may be as high as $255,000 \mathrm{~km} / \mathrm{h}$. The temperature may even rise to $3500^{\circ} \mathrm{C}$ for several seconds [79]. Metals on the hot surface react with $\mathrm{O}$ and $\mathrm{O}_{2}$. Metals can then also react with $\mathrm{N}_{2}$ and $\mathrm{CO}_{2}$. Oxides, hydroxides, $\mathrm{N}$-compounds and carbonates are formed.

Ablated compounds immediately start to descend. In continuous reactions their molecular weights increase varyingly. More or less separated layers start to form. The density difference between them and the ambient air decreases, so their rate of descent slows.

Ablation is most intensive at an altitude of $95 \mathrm{~km}$ [80]. At an altitude of 81 to $83 \mathrm{~km}$ the sizes of the condensation nuclei are already so large that they are able to trigger the formation of nanocrystalline ice particles. When ice has evaporated at 70 to $75 \mathrm{~km}$, metallic nuclei continue to grow and descend. In the upper stratosphere they have reached dimensions from $200 \mathrm{~nm}$ to $40 \mu \mathrm{m}$, and are called meteoric smoke particles (MSP) [81]. Ultimately, it may take up to four years before the MSPs hit the ground.

Observations of NLCs are restricted to the upper mesosphere above the boreal areas in summertime. However, the two mesospheric maxima in the water profile above the equatorial areas suggest that ice forms throughout Earth's mesosphere at an altitude of 81 to 83 $\mathrm{km}$, regardless of season.

\subsubsection{Apparent Movements of NLCs}

When observed visually or by radar from the ground, NLCs seem to be moving rather fast. Their direction of movement is opposite that of Earth's rotation around its axis. This movement is taken as evidence of winds in the upper mesosphere. However, there are no known and experimentally proven physical factors which could generate winds at that altitude.

Of the atmospheric mass, $99.99 \%$ is below an altitude of $80 \mathrm{~km}$. The gravitational force of Earth is not strong enough to bind the gas molecules above $80 \mathrm{~km}$ as tightly as the solid/liquid mass on the surface is. Gas molecules lag relative to the surface. An observer on the surface senses that the NLCs are moving even though he or she is actually moving faster relative to the clouds. An illusion of local movement at an altitude of 81 to $83 \mathrm{~km}$ in a clockwise direction is created. It is more relevant to suppose that the NLCs are stationary relative to the ambient air at that particular elevation range.

\section{Conclusions}

Due to buoyancy, methane molecules and water vapor $\left(\mathrm{H}_{2} \mathrm{O}_{(\mathrm{g})}\right)$ ascend in the atmosphere. Already in the stratosphere most of the methane is destroyed by chemical reactions. The rest of them are photodissociated by UV photons of $\lambda<140 \mathrm{~nm}$ in the mesopause. Above $100 \mathrm{~km}$, appreciable amounts of $\mathrm{CH}_{4}$ molecules do not even exist.

At an altitude of 81 to $83 \mathrm{~km}$, the ascending $\mathrm{H}_{2} \mathrm{O}_{(\mathrm{g})}$ condenses into ice crystals. The oxidation of metals ablated from meteorites creates compounds which act as condensation nuclei. Due to the lack of buoyance, the ice crystals that are formed descend to an altitude of 70 to 75 $\mathrm{km}$. There ice is sublimated back into $\mathrm{H}_{2} \mathrm{O}_{(\mathrm{g})}$. An upper mesospheric water mini cyle is formed. In boreal summer evenings, the ice layer at 81 to $83 \mathrm{~km}$ is visually observable from the ground, which results in the phenomenon known as noctilucent clouds.

Nowadays, the amount of $4.8 \times 10^{11} \mathrm{~g}$ of $\mathrm{H}_{2} \mathrm{O}_{(\mathrm{g})}$ is annually photodissociated in the mesopause. It produces $1.33 \times 10^{10} \mathrm{~mol} \times \mathrm{a}^{-1}$ of $\mathrm{O}_{2}$. With that rate of accumulation, the PAL level of $\mathrm{O}_{2}$ would have been produced within 2.5 billion years from the beginning of Earth. During the steam atmosphere phase in the early Precambrian era, the photodissociation of $\mathrm{H}_{2} \mathrm{O}_{(\mathrm{g})}$ was much more intensive. Earth had probably received an oxygenated atmosphere already by the end of $4.54 \times 10^{9}$ years.

The middle mesospheric ozone maximum (MMM) is formed in the wintertime at an altitude of 70 to $75 \mathrm{~km}$. Its location $\mathrm{O}_{2}\left({ }^{1} \Delta_{g}\right)$ is restricted between the northern mid-latitudes and somewhat north from the Arctic Circle, and symmetrically in the Southern Hemisphere. Daytime ozone concentration is kept at a low but stable level by intensive solar radiation. During the civil and nautical twilight, the intensity of the sun's rays decreases dramatically. Ozone, being the weak oxygen species, gains the most from this decrease. Its concentration increases to the maximum just before the dark.

Excited $\mathrm{O}_{2}\left(\mathrm{~b}^{1} \Sigma_{g}^{+}\right)$and $\mathrm{O}_{2}\left({ }^{1} \Delta_{g}\right)$ molecules maintain the ozone concentration and excited triplet state ozone $\left(\mathrm{O}_{3}{ }^{*}\right)$ molecules fuel the process with oxygen atoms via spontaneous dissociation or via chemical reactions. During winter, the solar radiation angle $\left(\theta_{\mathrm{s}}\right)$ decreases two times slower at the high latitudes than it does at the mid-latitudes. IR radiation has twice as much time to affect $\mathrm{O}_{2}$ and $\mathrm{O}_{3}$ molecules during the twilight. The production of $\mathrm{O}_{2}\left({ }^{1} \Delta_{g}\right)$ and $\mathrm{O}_{3}{ }^{*}$ is then more efficient in the high latitudes. As a result, the amplitude of the MMM layer in terms of ozone concentration increases when moving from the mid-latitudes towards the high ones. The ozone concentration drops only slightly during the dark period of the night.

\section{Acknowledgements}

I am very grateful to Matthew Wuethrich from the University of Jyväskylä Language Services for revising the English of the manuscript. I thank my wife Ritva for her support.

\section{REFERENCES}

[1] U. von Zahn, J. Höffner, V. Eska and M. Alpers, The mesopause altitude: Only two distinctive levels worldwide? Geophysical Research Letters, Vol. 23, No. 22, 3231-3234, 
1996. https://doi.org/10.1029/96GL03041.

[2] F. Verniani and E. R. Viani, Diurnal and seasonal variation of the atmospheric temperature at the 90-kilometer altitude. Journal of Geophysical Research, Oceans and Atmospheres, Vol. 77, No. 24, 4581-4585, 1972. https://doi.org/10.1029/ JC077i024p04581.

[3] Office of Commercial Space Transportation, Draft Programmatic Environmental Impact Statement for Commercial Reentry Vehicles, p. 4-39-4-40, 1992 Washington D. C.

[4] Meteorites Most Likely Source of Earth's Water, Astrobiology Magazine, Jul 13, 2012, https://www.astrobio.net/meteoritescomets-and-asteroids/ meteorites-most-likely-source-of-earths-water/

[5] NASA, Asteroid Fast Facts, 2014.https://www.nasa.gov/m ission_pages/asteroids/overview/fastfacts.html.

[6] C. Deziel, What Happens When a Meteoroid Enters Earth's Atmosphere? April 25, 2017, https://sciencing.com/happen s-meteoroid-enters-earths-atmosphere-3611.html.

[7] W. F. J. Evans, H. C. Wood and E. J. Llewellyn, Transmission of the infrared oxygen emission at $1.27 \mu \mathrm{m}$ in the atmosphere, Canadian Journal of Physics. Vol. 48, No. 6, 747-752, 1970. DOI: 10.1139/p70-094.

[8] W. F. J. Evans and E. J. Llewellyn, Measurements of mesospheric ozone from observations of the $1.27 \mu$ band, Radio Science, Vol. 7, No. 1, 45-50, 1972. https://doi.org/10.1029/RS007i001p00045.

[9] P. B. Hays and R. G. Roble, Observation of mesospheric ozone at low latitudes, Planetary and Space Science, Vol. 21, 273-279, 1973. DOI: 10.1016/0032-0633(73)90011-1.

[10] D. Offermann, K. U. Grossmann, P. Barthol, P. Knieling, M. Riese, and R. Trant, Cryogenic Infrared Spectrometers and Telescopes for the Atmosphere (CRISTA) experiment and middle atmosphere variability, Journal of Geophysical Research, Vol 104, 16,311- 16,325, 1999. https://doi.org/10.1029/1998JD100047.

[11] NASA, Jet Propulsion Laboratory: https://mls.jpl.nasa.gov/.

[12] L. Froidevaux, W.G. Read, T.A. Lungu, R.E. Cofield, E.F. Fishbein, et al., Validation of UARS Microwave Limb Sounder ozone measurements, Journal of Geophysical Research, Vol. 101, 10,017-10,060, 1996. https://doi.org/1 $0.1029 / 95 J D 02325$.

[13] ESA Earth Online, https://earth.esa.int/web/guest/missions /esa-operational-eo-missions/envisat/instruments/mipas.

[14] M. T. DeLand and R. P. Cebula, NOAA 11 Solar Backscatter Ultraviolet, model 2 (SBUV/2) instrument solar spectral irradiance measurements in 1989-1994: 2. Results, validation, and comparisons, Journal of Geophysical Research Atmospheres, Vol. 103, No. D13, 16251-16273, 1998. https://doi.org/10.1029/98JD01204.

[15] K. Wargan, I. Stajner, S. Pawson, R. B. Rood, W-w Tan, Assimilation of ozone data from the Michelson Interferometer for Passive Atmospheric Sounding, Quarterly Journal of the Royal Meteorological Society, Vol. 131, No. 611, 2713-2734, 2005 Part A. https://doi.org/10.1256/qj.04.184.
[16] A. Laeng, J. Plieninger, T. von Clarmann, U. Grabowski, G. Stiller, E. Eckert, N. Glatthor, F. Haenel, S. Kellmann, M. Kiefer, A. Linden, S. Lossow, L. Deaver, A. Engel, M. Hervig, I. Levin, M. McHugh, S. Noël, G. Toon, and K. Walker. Validation of MIPAS IMK/IAA methane profiles Atmospheric Measuring Techniques, Vol. 8, 5251-5261, 2015. DOI: 10.5194/amt-8-5251-2015.

[17] D. Marsh, A. Smith, G. Brasseur, M. Kaufmann and K. Grossmann, The existence of a tertiary ozone maximum in the high - latitude middle mesosphere, Geophysical Letters, Vol. 28, No. 24, 4531-4534, 2001. https://doi.org/10.1029/ 2001 GL013791.

[18] E. Kyrölä, J. Tamminen, G. W. Leppelmeier, V. Sofieva, S. Hassinen, A. Seppala, P. T. Verronen, J. L. Bertaux, A. Hauchecorne, F. Dalaudier, D. Fussen, F. Vanhellemont, O. Fanton d'Andon, G. Barrot, A. Mangin, B. Theodore, M. Guirlet, R. Koopman, L. Saavedra de Miguel, P. Snoeij, T. Fehr, Y. Meijer, and R. Fraisse, Nighttime ozone profiles in the stratosphere and mesosphere by the Global Ozone Monitoring by Occultation of Stars on Envisat, Journal of Geophysiscal Research, 111, D24306, 2006. DOI: 10.1029/2006JD007193.

[19] O. Jesse, Auffallende Abendscheinungen am Himmel, Meterologische Zeitschrift, Vol. (Jahrgang) 2, 311-312, 1885.

[20] R. Leslie, Sky glows, Nature Vol. 32, 245, 1885.

[21] T. W. Backhouse, The luminous cirrus clouds of June and July, Symons's Monthly Meteorological Magazine Vol. 20, $133,1885$.

[22] O. Jesse, Die Beobachtung der leuchntenden Wolken, Meteorologische Zeitschrift, Vol. (Jahrgang) 4, 179-181, 1887.

[23] G. Thomas, Mesospheric clouds and the physics of the mesopause region, Reviews of Geophysics, Vol. 29, 4 553$575,1991$.

[24] G. Thomas and J. Olivero, Climatology of Polar Mesospheric Clouds 2. Further Analysis of Solar Mesosphere Explorer Data, Journal of Geophysical Research, Vol. 94, D12, 14673-14681, 1989. https://doi.or g/10.1029/JD094iD12p14673.

[25] M. Hervig, R. Thompson, M. McHugh and L. Gordley, First confirmation that water ice is the primary component of polar mesospheric clouds, Geophysical Research Letters Vol. 28, No 6, 971-974, 2001. https://doi.org/10.1029/200 0GL012104.

[26] G. W. vanLoon and S. J. Duffy, Environmental Chemistry A Global Perspective, Oxford University Press, 49-50, 2005. DOI: 10.1016/0021-9169(72)90061-X

[27] B. J. Finlayson-Pitts and J. R. Pitts Jr. Chemistry of the Upper and Lower Atmosphere, Academic Press, p. 54 and p. 943, 2000.

[28] M. De Maziere, C. Vigouroux, P. F. Bernath, P. Baron, T. Blumenstock, C. Boone, C. Brogniez, V. Catoire, M. Coffey, P. Duchatelet, D. Griffith, J. Hannigan, Y. Kasai, I. Kramer, N. Jones, E. Mahieu, G. L. Manney, C. Piccolo, C. Randall, C. Robert, C. Senten, K. Strong, J. Taylor, C. Tetard, K. A. Walker and S. Wood, Validation of ACE-FTS v2.2 methane profiles from the upper troposphere to the lower mesosphere, Atmospheric Chemistry and Physics, 
Vol. 8, 2421-2435, 2008. http://citeseerx.ist.psu.edu/viewd oc/download?doi=10.1.1.1016.4323\&rep=rep1\&type $=$ pdf.

[29] https://www.engineeringtoolbox.com/gas-density-d_158.ht $\mathrm{ml}$

[30] B. C. Kindel, P. Pilewskie, K. S. Schmidt, T. Thornberry, A. Rollins, and T. Bui, Upper-troposphere and lower-stratosphere water vapor retrievals from the 1400 and $1900 \mathrm{~nm}$ water vapor bands, Atmospheric Measurement Techniques, Vol. 8, 1147-1156, 2015. www.atmos-meas-te ch.net/8/1147/2015/doi:10.5194/amt-8-1147-2015.

[31] https://physics.info/density/.

[32] P. Warneck, Chemistry of the Natural Atmosphere, p. 719 and 727, 2000, Academic Press, New York. ISBN $0-12-735632-0$.

[33] S. Fueglistaler, A. E. Dessler, T. J. Dunkerton, I. Folkins, Q. $\mathrm{Fu}$ and P. W. Mote. Tropical Tropopause Layer, Reviews of Geophysics, Vol. 47, RG1004, 2009. DOI: 10.1029/2008RG000267.

[34] S. Lossow, M. Khaplanov, J. Gumbel, J. Stegman, G. Witt, P. Dalin, S. Kirkwood, J. D. Schmidlin, K. H. Fricke and A. Blum, Middle atmospheric water vapour and dynamics in the vicinity of the polar vortex during the Hygrosonde-2 campaign, Atmos. Chem. Phys. Discuss. Vol. 8, 12227 12252, 2008

www.atmos-chem-phys-discuss.net/8/12227/2008/.

[35] R. S. O'Brien and W. F. J. Evans, Rocket measurements of the distribution of water vapor in the stratosphere at high latitudes, Journal of Geophysical Research, Vol. 89, No. C12, 12101 - 12107, 1981. https://doi.org/10.1029/JC086i C12p12101.

[36] A. von Engeln, J. Langen, T. Wehr, Retrieval of upper stratospheric and mesospheric temperature profiles from Millimeter-Wave Atmospheric Sounder Data, Journal of Geophysical Research, Vol. 103, No. D24, 31,735 - 31,748, 1998.

http://www.sat.ltu.se/members/ave/publications/papers/JG RD2-1998900035.pdf.

[37] M. Y. Kulikov, A. M. Feigin and G. R. Sonnemann. Retrieval of water vapor profile in the mesosphere from satellite ozone and hydroxyl measurements by the basic dynamic model of mesospheric photochemical system, Atmospheric Chemistry and Physics, Vol. 9, 8199-8210, 2009.

https://www.atmos-chem-phys.net/9/8199/2009/acp-9-819 9-2009.pdf.

[38] S. Lossow, J. Urban, J. Gumbel, P. Eriksson and D. Murtagh, Observations of the mesospheric semi-annual oscillation (MSAO) in water vapour by Odin/SMR, Atmospheric Chemistry and Physics, Vol. 8, 6527-6540, 2008. www.atmos-chem-phys.net/8/6527/2008/.

[39] S. J. Blanksby and G. B. Ellison, Bond Dissociation Energies of Organic Molecules, Accounts of Chemical Research, Vol. 36 No. 4, 255-263, 2003. DOI: $10.1021 /$ ar020230d, https://datapdf.com/bond-dissociation-energies-of-organicmolecules-accounts-of56889.html.

[40] M. Brouard and J. P. Simons, The Stereodynamics of Photon Initiated Bimolecular Reactions. In K. Liu and A. Wagner (Eds), The Chemical Dynamics and Kinetics of
Small Radicals. Part II, Advanced Series in Physical Chemistry, Vol. 6. Chapter 18, p. 830. 1995. World Scientific, Singapore.

[41] K. Watanabe and M. Zelikoff, Absorption coefficients of water vapor in the vacuum ultraviolet, Journal of the Optical Society of America, Vol. 43, 753-5, 1953.

[42] C. Romanzin, M.-C. Gazeau,Y.Bénilan, E. Hébrard, A. Jolly, F. Raulin, S. Boyé-Péronne, S. Douin, D. Gauyacq, Methane photochemistry: A brief review in the frame of a new experimental program of Titans atmosphere simulations, Advances in Space Research Vol 36, No. 2, 258-267, 2005. DOI:10.1016/j.asr.2005.03.079.

[43] B. Ruscic, A. F. Wagner, L. B. Harding, R. L. Asher, D. Feller, D. A. Dixon, K. A. Peterson, Y. Song, X. Qian, C.-Y. $\mathrm{Ng}$, J- Liu, W. Chen, and D. W. Schwenke, On the Enthalpy of Formation of Hydroxyl Radical and Gas-Phase Bond Dissociation Energies of Water and Hydroxyl. The Journal of Physical Chemistry, Vol. 106, 2727 - 2747, 2002. DOI: 10.1021/jp013909s.

[44] G. A. Cruz-Diaz, G. M. Muñoz Caro, Y-J. Chen and T-S. Yih, Vacuum-UV spectroscopy of interstellar ice analogs I. Absorption cross-sections of polar-ice molecules, Astronomy and Astrophysics, Vol. 562, A119, 2014. https://doi.org/10.1051/0004-6361/201322140.

[45] C. A. Cantrell, A. Zimmer, and G. S. Tyndall, Absorption cross sections for water vapor from 183 to $193 \mathrm{~nm}$, Geophysical Research Letters, Vol. 24, No. 17, 2195-2198, 1997.https://agupubs.onlinelibrary.wiley.com/doi/pdf/10.1 029/97GL02100.

[46] V. I. Krassovsky, Hydroxyl Emission in the Upper Mesosphere, Planetary and Space Science, Vol. 10, 7 - 17, 1963. https://doi.org/10.1016/0032-0633 (63)90002-3.

[47] H. Gao, J. Xu, W. Ward, A. K. Smith and G-M Chen, Double-layer structure of $\mathrm{OH}$ dayglow in the mesosphere, Journal of Geophysical Research, Space Physics, Vol. 120, No. 7, 5778-5787, 2015. https://doi.org/10.1002/2015JA02 1208.

[48] J. C. G. Walker, Evolution of the Atmosphere, Macmillan, New York, p. 39, p. 201, 1977. ISBN 0-02-854390-4.

[49] CRC Handbook of Physics and Chemistry, p. F-195, 55 ${ }^{\text {th }}$ Edition 1974 - 1975, CRC Press. ISBN 087819-454-1.

[50] G. Schubert, D. L. Turcotte, P. Olson.; Mantle Convection in the Earth and Planets, Cambridge University Press, 2001. ISBN $052135367 \mathrm{X}$ hardback. https://earthscience.rice.edu/wp content/uploads/2017/08/SchubertTurcotteOlson2001_Cha pter13.pdf.

[51] D. Biello, Partial Meltdowns Led to Hydrogen Explosions at Fukushima Nuclear Power Plant, Scientific American, March 14, 2011.

[52] IAEA-TECDOC-1661, Mitigation of Hydrogen Hazards in Severe Accidents in Nuclear Power Plants, 2011. ISBN: 978-92-0-116510-7.https://www-pub.iaea.org/MTCD/Publ ications/PDF/TE_1661_Web.pdf.

[53] Chemical Thermodynamics of Iron, Part 1, NEA No. 6355, OECD, p. 199, 2013. https://www.oecd-nea.org/dbtdb/pub s/6355-vol13a-iron.pdf.

[54] https://en.wikipedia.org/wiki/Superheated_steam. 
[55] G. B. Dalrymple, The Age of the Earth, p. 298, 1991, Stanford University Press, Stanford CA. ISBN $0-8042-2331-1$.

[56] The Unexpected Temperature Profile of Venus's Atmosphere. Venus Express, ESA, 2007. http://www.esa.int/Our Activities/Space Science/Venus Express/The_unexpected_temperature_profile_of Venus_s atmospherehttps://atct.anl.gov/Thermochemical\%20Data/ version\%201.118/species/?species_number $=37$.

[57] J. W. H. Chi and C. E. Landahl, Hydrogen Reactions with Graphite Materials at High Temperatures and Pressures, Journal of Nuclear Applications, Vol. 4, No. 3, 159-169, 1968. https://doi.org/10.13182/NT68-A26380.

[58] P. Dockrill, Solar Wind Is Blasting Earth's Oxygen onto The Surface of The Moon, Science Alert, 31 Jan 2017. https://www.sciencealert.com/solar-wind-is-blasting-earths-oxygen-onto-the-surface-of-the-moon.

[59] https://www.bp.com/en/global/corporate/energy-economi cs/statistical-review-of-world-energy/natural-gas/natural-g as-reserves.html.

[60] L. Moreira, K. Hocke, and N. Kämpfer, Comparison of ozone profiles and influences from the tertiary ozone maximum in the night-to-day ratio above Switzerland. Atmospheric Chemistry and Physics, Vol. 17, 1025910268, 2017, https://doi.org/10.5194/acp-17-10259-2017.

[61] A. E. E. Rogers, M. Lekberg, P. Pratap, Seasonal and Diurnal Variations of Ozone near the Mesopause from Observations of the $11.072-\mathrm{GHz}$ Line. Journal of Atmospheric and Oceanic Technology, Vol. 26, 2192-2199, 2009. http://dx.doi.org/10.1175/2009jtecha1291.1.

[62] J. Rieker, Sunset and Sunrise in the Ionosphere: Effects on the Propagation of Longwaves, Journal of Research of the National Bureau of Standards-D, Radio Propagation Vol. 67D, No, 2, $119-138,1963$.

[63] M. Spittshan, G. K. Aguirre, D. H. Brainard and A. M. Sweeney, Variation of outdoor illumination as a function of solar elevation and light pollution, Scientific Reports, Vol. 6, Article number: 26756, 2016. DOI: 10.1038/srep26756.

[64] http://www.solartopo.com/solar-orbit.htm.

[65] R. Siebert, P. Fleurat-Lessard, R. Schinke, M. Bittererova and S. C. Farantos, The vibrational energies of ozone up to the dissociation threshold: Dynamics calculations on an accurate potential energy surface, The Journal of Chemical Physics Vol. 116, No. 22, 9749-9767, 2002. https://doi.org/10.1063/1.1473664.

[66] H. Ågren, O. Vahtras and B. Minaev, Response Theory of Calculations of Spi-Orbit Coupling Phenomena in Molecules. In: P.-O. Löwdin, J. S. Sabin and M. C. Zerner (Eds.), Advances in Quantum Chemistry, Vol. 27, p. 106, 1996. Academic Press. ISBN 0-12-034827-6.

[67] V. Gorshelev, A. Serdyuchenko, M. Weber, W. Chehade, and J. P. Burrows. High spectral resolution ozone absorption cross-sections - Part 1: Measurements, data analysis and comparison with previous measurements around $293 \mathrm{~K}$, Atmospheric Measuring Techniques, Vol. 7, 609-624, 2014. DOI: 10.5194/amt-7-609-2014.

[68] K. M. Smith and D. A. Newnham, Near-infrared absorption spectroscopy of oxygen and nitrogen gas mixtures, Chemical Physical Letters, Vol. 308, No 1-2, 1-6, 1999. https://doi.org/10.1029/1999JD901171.

[69] J. Gumbel, D. P. Murtagh, P. J. Espy, G. Witt and F. J. Schmidlin, Odd oxygen measurements during the Noctilucent Cloud ' 93 rocket campaign, Journal of Geophysical Research Vol. 103, 23399-23414,1998. DOI:10.1029/98JA02155.

[70] D. A. Newnham and J. Ballard, Visible absorption cross-sections and integrated absorption intensities of molecular oxygen $\left(\mathrm{O}_{2}\right.$ and $\left.\mathrm{O}_{4}\right)$, Journal of Geophysical Research, Vol. 103, No. D22, 28,801-28,816, 1998.

[71] T. G. Slanger and P. C. Cosby, $\mathrm{O}_{2}$ Spectroscopy below 5.1 eV, The Journal of Physical Chemistry, Vol. 92, 267-282, 1988. DOI: $10.1021 / \mathrm{j} 100313 \mathrm{a} 008$.

[72] P. D. Cooper, R. E. Johnson and T. I. Quickenden, A review of possible optical absorption features of oxygen molecules in the icy surfaces of outer solar system bodies, Planetary and Space Science Vol. 51, 183-192, 2003. DOI: 10.1016/S0032-0633(02)00205-2.

[73] W. D. McGrath and R. G. W Norrish, Production of Vibrationally Excited Oxygen Molecules in the Flash Photolysis of Ozone, Nature, Vol. 180, 1272-1273, 1957. DOI: $10.1038 / 1801272 b 0$.

[74] R. P. Wayne, The photochemical formation of electronically excited oxygen molecules in the atmosphere, Quarterly Journal of Royal Meteorological Society, Vol. 93, No. 395, 69-78, 1967.https://doi.org/10.1002/qj.49709339 506.

[75] U. Schurath. The energy pooling reaction $2 \mathrm{O}_{2}\left({ }^{1} \Delta \mathrm{g}\right) \rightarrow$ $\mathrm{O}_{2}\left({ }^{3} \Sigma_{\mathrm{g}}^{-}\right)+\mathrm{O}_{2}\left({ }^{1} \Sigma_{\mathrm{g}}^{+}\right.$; formation, relaxation, and quenching of vibrationally excited $\mathrm{O}_{2}\left({ }^{1} \Sigma^{+}\right.$), Journal of Photochemistry, Vol 4. No. 3, 215-226, 1975.https://doi.org/10.1016/00472670 (75) $80007-4$

[76] W. B. Demore and O. F. Raper, Deactivation of $O\left({ }^{1} D\right)$ in the Atmosphere, Astrophysical Journal, Vol. 139,13811382,1964

[77] R. P. Wayne and J. N. Pitts Jr., Rate Constant for the Reaction $\mathrm{O}_{2}\left({ }^{1} \Delta_{g}\right)+\mathrm{O}_{3} \rightarrow 2 \mathrm{O}_{2}+\mathrm{O}^{*}$, The Journal of Chemical Physics Vol. 50, 3644-3646, 1969.https://doi.org/10.1063/ 1.1671606 .

[78] Daily Mail, Mail Online, 10 .5. 2018, http://www.dailymai 1.co.uk/sciencetech/article-2634962/Watch-5-000-meteoroi ds-bombard-Earth-day-REAL-TIME-Map-plots-comet-deb ris-burning-heads.html\#ixzz5F6nBI88b.

[79] V. Della Corte, F. J. M. Rietmeijer, A. Rotundi, M. Ferrari and P. Palumbo, Meteoric $\mathrm{CaO}$ and carbon smoke particles collected in the upper stratosphere from an unanticipated source, Tellus B: Chemical and Physical Meteorology, Vol. 65, No.1, 20174, 2013. DOI: 10.3402/tellusb.v65i0.20174, https://doi.org/10.3402/tellusb.v65i0.20174.

[80] R. P. Wayne, Chemistry of Atmospheres, p. 544, 2000, Oxford University Press. ISBN 019850375 X.

[81] J. M. C. Plane, W. Feng and E. C. M. Dawkins, The Mesosphere and Metals: Chemistry and Changes, Chemical Reviews, Vol. 115, No. 10, 4497-4541, 2015.DOI: 10.10 $21 / \mathrm{cr} 500501 \mathrm{~m}$ 